ARTICLE

\title{
Debt sustainability of states in India: An assessment
}

\author{
Balbir Kaur $^{1} \cdot$ Atri Mukherjee $^{1} \cdot$ Anand Prakash Ekka ${ }^{1}$
}

Published online: 23 July 2018

(c) The Author(s) 2018

\begin{abstract}
The debt position of the state governments in India, which deteriorated sharply between 1997-1998 and 2003-2004, has witnessed significant improvement since 2004-2005. Debt sustainability analysis based on empirical estimation of inter-temporal budget constraint and fiscal policy response function in a panel data framework, covering 20 Indian states for the period 1980-1981 to 2015-2016, indicates that the debt position at the state level is sustainable in the long run. The increase in contingent liabilities of states and take-over of large chunk of these liabilities through debt restructuring of State Power Distribution Companies, however, would adversely affect the debt position of states.
\end{abstract}

Keywords Gross fiscal deficit $\cdot$ Public debt $\cdot$ State governments

JEL Classification $\mathrm{H} 62 \cdot \mathrm{H} 63 \cdot \mathrm{H} 70$

\section{Introduction}

In line with an overall decentralizing trend, the sub-national governments worldwide have been entrusted with increasing responsibilities towards delivery of public goods and services, and investment in physical and social infrastructure. As the concomitant expenditure requirements generally fall short of own revenue receipts and inter-governmental transfers from the national authorities, the sub-national governments have to depend on borrowed resources to finance such expenditure. However, the borrowing limits of sub-national governments in various countries are subject to either regulatory restrictions or self-imposed fiscal discipline, given the underlying requirement to ensure debt sustainability at the sub-national level.

In India, the state governments have been playing an important role in discharging various functions assigned to them under the Constitution. As the non-debt

Atri Mukherjee

atrimukherjee@rbi.org.in

1 Department of Economic and Policy Research, Reserve Bank of India, Amar Building, Fort, Mumbai 400001, India 
receipts of states are often not sufficient to provide the requisite financial resources, they resort to borrowings to meet various development needs. It is often said that borrowing per se is not bad provided it is used for productive purposes. While this may be a desirable goal, the actual utilisation of borrowed resources may not necessarily be only for productive purposes due to various reasons. However, the accumulation of debt liabilities, if left uncontrolled, could cause macroeconomic and financial stability issues.

The evolution of debt position of state governments in India has seen several phases: a comfortable position prior to 1997-1998 to a phase of sharp deterioration and fiscal stress during 1997-1998 to 2003-2004 and then to a phase of significant improvement since 2004-2005. While the debt liabilities of states increased sharply during 1997-1998 to 2003-2004, the subsequent period has been a phase of consolidation, attributable, among others, to the implementation of fiscal rules through the enactment of Fiscal Responsibility and Budget Management (FRBM) Acts/Fiscal Responsibility Legislations (FRLs) at the state level in early 2000s. These fiscal consolidation initiatives were complemented by debt and interest relief measures of the central government, and also supported by a favourable macroeconomic environment following the high growth phase and a reversal of the interest rate cycle in the mid-2000s. Majority of the states adhered to the debt targets set for them by the Thirteenth Finance Commission (FC-XIII) for the period 2010-2014, even as some of them breached their respective debt targets and continued to have unsustainable debt positions. In the recent period, the signs of fiscal stress have re-emerged on the back of poor performance of state public sector enterprises. With several states assuming additional debt liabilities as part of financial and operational restructuring of state power distribution companies, there is an inherent risk in terms of debt servicing capacity and soundness of fiscal performance parameters of states. In addition, the adoption of farm loan waivers by different state governments, viz, Uttar Pradesh, Punjab, Rajasthan, Maharashtra and Karnataka is likely to further enhance their fiscal burden.

It is against the above backdrop that this paper assesses the issue of debt sustainability of states in India. The issue has become all the more relevant after the release of the report of the FRBM Review Committee (Chairperson: N. K. Singh), 2017, which suggests using debt as the primary target for fiscal policy. The debt sustainability analysis carried out in this paper is based on three approaches: indicatorbased analysis, estimation of both inter-temporal budget constraint and fiscal policy response function (to deterioration in debt position) at the state level. While the debt sustainability analysis per se is in respect of debt stock or outstanding liabilities of the state governments, this has been extended to highlight the fiscal implications of off-budget items, viz, contingent liabilities of states, guarantees extended by them to state power utilities and finally the take-over of debt liabilities of these utilities by the state governments that have decided to participate in the restructuring scheme implemented by the central government.

The paper is organised as follows. Section 2 defines debt sustainability. Section 3 presents a brief overview of various studies that have examined debt sustainability at the state level in the Indian context. An analytical presentation of the theoretical basis underlying fiscal/debt sustainability analysis is provided in Sect. 4. Some stylised facts 
relating to the evolution of state government debt in India are presented in Sect. 5. Section 6 presents an empirical assessment of debt sustainability at the state level based on different approaches. The rationale for extending the conventional debt sustainability analysis to include off-budget fiscal position of states in the context of additional debt liabilities which have arisen on account of take-over of debt of state power utilities is explained in Sect. 7. The concluding observations are covered in Sect. 8.

\section{Defining debt sustainability}

Debt sustainability is a term that has been used with increasing frequency in the academic literature and multilateral policy discussions, but with different connotations under different circumstances (Balassone and Franco 2000; Chalk and Hemming 2000). How one defines debt sustainability could affect the conclusion one arrives about the sustainability or otherwise of debt in an economy. In the pioneering work on debt sustainability, based on the post-Second World War US data, Domar (1944) pointed out that primary deficit path can be sustained as long as real growth of the economy remains higher than the real interest rate. Buiter (1985) suggested that sustainable fiscal policy is one that is capable of keeping the public sector net worth to output ratio at its current level. Blanchard (1990) provided two conditions for sustainability viz., (a) the ratio of debt to GNP should eventually converge back to its initial level, and (b) the present discounted value of the ratio of primary surpluses to GNP should be equal to the current level of debt to GNP. Buiter (1985), Blanchard (1990) and Blanchard et al. (1990) considered debt level as sustainable if a country's debt to GDP ratio remains stable, and if the economy generates debt stabilising primary balance to cover that debt in future.

In terms of the standard definition of fiscal sustainability, the ratio of outstanding debt and debt servicing to GDP, in a steady state, should not increase over time (World Bank and IMF 2010). The focus in this approach is on stabilising the debtto-GDP ratio. International Monetary Fund (2011) considers a set of fiscal policies as sustainable in case a borrower is able to continue servicing its debt without an unrealistic large future correction to its income and expenditure.

Typically, conventional debt sustainability analysis is an accounting-based approach linked to the inter-temporal budget constraint as follows:

$$
B_{t+1}=(1+r) B_{t}-P S_{t},
$$

which states that public debt at the beginning of the period $t+1$ i.e., $\left(\mathrm{B}_{t+1}\right)$ equals past period debt including interest payments but adjusted for primary balance, depending on whether there is primary surplus or deficit. Recursively solving (1) with time period $(t)$ starting at 0 and extending up to infinity, we get

$$
B_{0}=\sum_{t=1}^{\infty} P S_{t} /(1+r)^{t}+\operatorname{Lim}_{t \rightarrow \infty} B_{t} /(1+r)^{t}
$$


Fiscal policy is said to be sustainable, if the initial stock of debt is equal to the sum of present discounted values of primary surpluses. Alternatively, the present value of revenues must be equal to the present value of spending including interest on the public debt plus repayment of the debt itself. This is defined as the inter-temporal budget constraint and is satisfied if the discounted sum of end-period debt converges to zero, i.e., $\operatorname{Lim} B_{t} /(1+r)^{t}$ becomes 0 . This transversality condition rules out a 'Ponzi' scheme and requires that debt should not grow at a rate faster than interest rate. The solvency condition for government debt implies that future budget surpluses would be sufficient to meet current debt liabilities.

The transversality condition relating to the long-term solvency of public debt, when expressed in terms of GDP ratio, states that the GDP growth rate has to be lower than the interest rate so that the discounted terminal period debt ratio converges to zero. This implies that in case of a positive initial public debt, the sum of the cumulated discounted future public surpluses should exceed the sum of the cumulated discounted future public deficits. However, if the rate of growth of GDP is higher than the interest rate, there would be reverse stabilising effect on the ratio of debt to GDP even if a sub-national government is accumulating primary deficit. It may not always be possible to sustain high growth situation and/or maintain the positive growth-interest differential for all times to come; and a positive primary balance may become necessary to ensure sustainability of public debt and avoid Ponzi scheme.

\section{Review of literature}

In the theoretical literature, the rationale for maintaining low/sustainable level of debt is attributed, among others, to the need to ensure sustainability of fiscal policy, provide fiscal space for undertaking counter-cyclical policy, absorbing contingent liabilities without threatening debt sustainability, reducing vulnerability to crises and optimizing growth by reducing the risk of crowding out of private investment, while taking into account concerns relating to inter-generational equity and future spending needs. In the Indian context, there are several empirical studies, which have examined fiscal/debt sustainability of states (Table 1).

Overall, the empirical studies on debt sustainability at the state level in India indicate a mixed picture. While some of the studies point out that the debt position of states is unsustainable, others have drawn attention to the declining debt-GSDP ratios at the state level and attributed this improvement to the strong growth performance and the implementation of fiscal rules during 2003-2012. It is held that a slowdown in growth momentum could pose risk to the achievement of envisaged gross fiscal deficit and debt-GSDP targets under the medium-term scenario. 


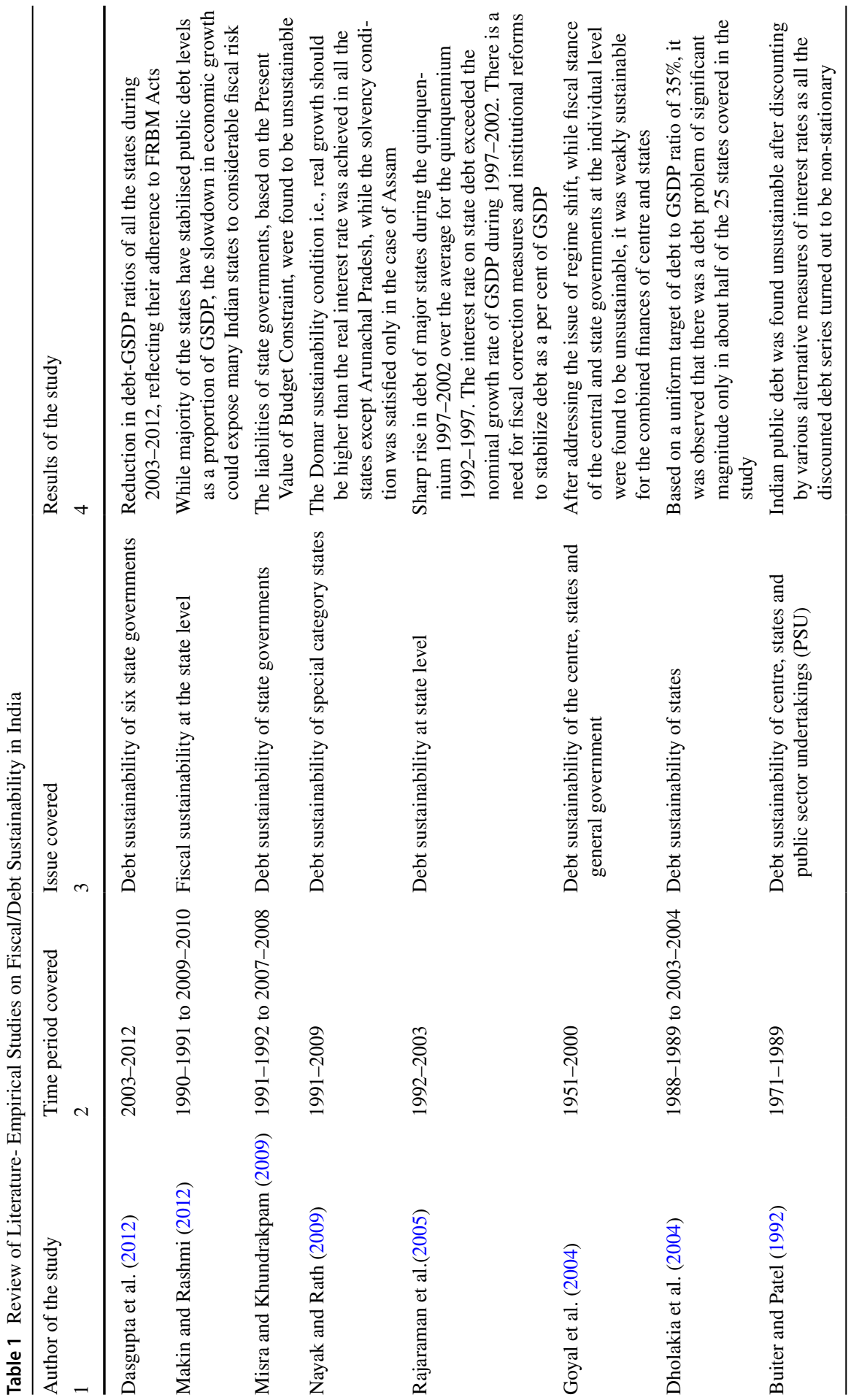




\section{Need for assessment of debt sustainability at the state level}

Globally, sub-national governments (SNGs) have assumed importance in the wake of their increasing role in provision of various essential services while also catering to urban infrastructure requirements. In this process, their resource base has also expanded with growing dependence on borrowed funds. However, the borrowing limits of SNGs are, by and large, regulated by the upper tiers of government in countries with a federal system. In countries with 'golden rules' in place, borrowings are required to be authorised, and in some countries (France, Ireland and the UK), the central government could directly restrict borrowings by lower levels of government. In Sweden, it is mandatory for SNGs to balance their budgets by year-end; in case of deficits, balance has to be restored in 2 years. Apart from the imposition of restrictions on borrowing limits, the practice of having explicit co-ordination agreements between different government tiers have also been observed.

In the Indian context, the starting point of the debt sustainability exercise is to examine whether the state governments really face hard budget constraint? Article 293 of the Indian Constitution stipulates that a state may not without the consent of the Government of India raise any loan if there is still outstanding any part of a loan which has been made to the state by the Government of India or by its predecessor Government, or in respect of which a guarantee has been given by the Government of India or by its predecessor Government. This implies that the state governments do not have unrestricted power to borrow as long as they are indebted to the Centre. In addition, states are also prohibited from borrowing abroad with the exception of loans from multilateral financial institutions intermediated by the central government.

In addition to the restrictions under Article 293 of the Constitution of India, the state governments have gone ahead with the self-imposed restrictions through the enactment of FRBM Acts/FRLs. The implementation of a rule-based fiscal discipline mechanism under these enactments since the early 2000s has been marked by a gradual move towards sustainability of their fiscal and debt positions, with majority of the states achieving the thirteenth Finance Commission (FC-XIII) targets as also their self-imposed targets. However, a few states continue to face fiscal stress and their debt positions remain an area of concern. Furthermore, notwithstanding strict monitoring of overall borrowing limits and adherence to various restrictions, the state governments have been able to raise additional 'off-budget' borrowings with guarantees through state-controlled Special Purpose Vehicles (SPVs) and/or state-owned public sector enterprises (SPSEs), which have in-built risks of various kinds. It is against this backdrop that the following Section presents the evolution of debt position of state governments beginning 1980-1981. 
Chart I: Key Fiscal Indicators of State Governments
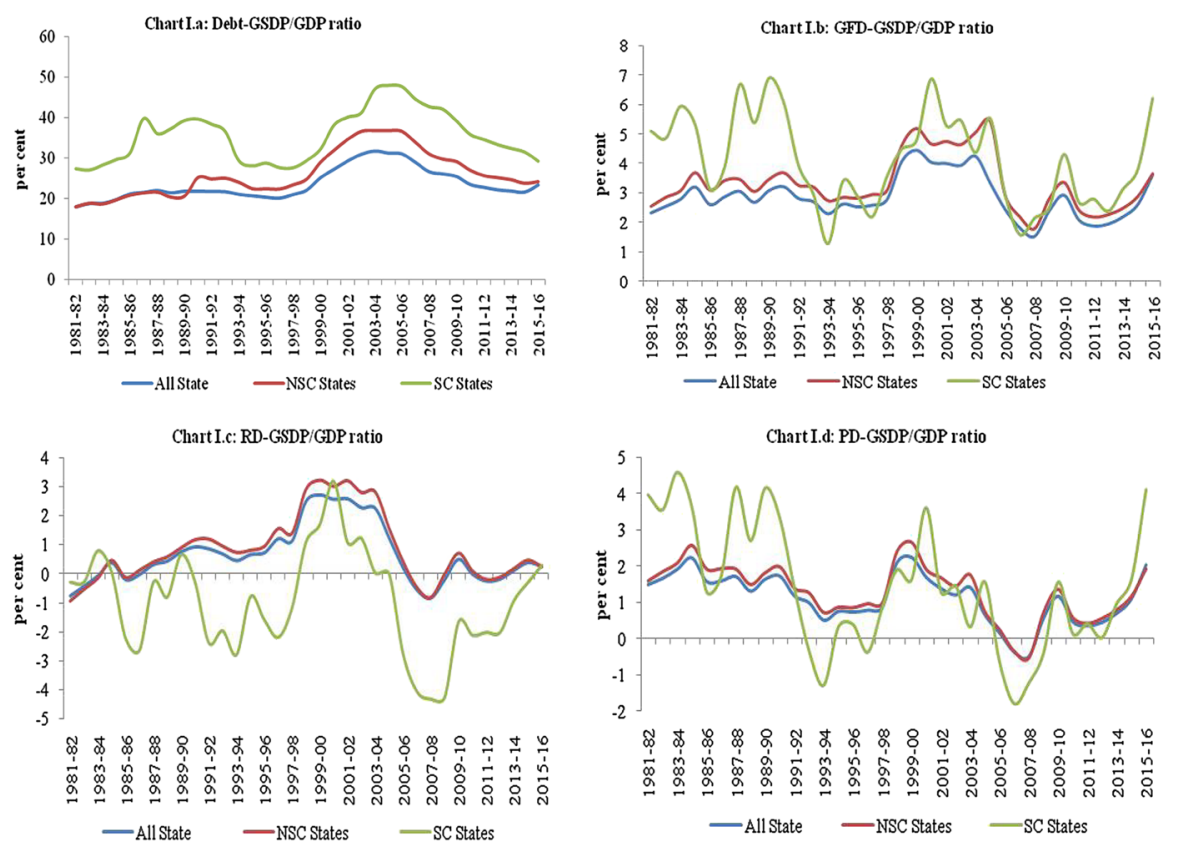

Fig. 1 Key Fiscal Indicators of State Governments. 1. Ratios pertaining to 'All States' are as percentage to GDP. 2. NSC and SC refer to non-special and special category states, respectively

\section{Evolution of state government debt in India: some stylised facts}

The fiscal position of states in India, which had remained comfortable in the first three decades since independence, exhibited signs of fiscal stress since the mid1980s. The average debt-GDP ratio inched up slightly from $18.3 \%$ during the 1980 s to $20.8 \%$ during the 1990 s. The period from $1997-1998$ to $2003-2004$ was, however, marked by a sharp deterioration in key fiscal indicators of states, which was reflected in an increase of around 6 percentage points in average debt-GDP ratio to $26.8 \%$ and further to a high of $31.8 \%$ in end-March 2004 (Fig. 1a).

In recognition of the need for fiscal discipline, the state governments adopted a rule-based fiscal framework through the enactment of FRBM Acts/FRLs, which also included stipulation of ceilings on total liabilities and in some cases on debt-service liabilities (Goa, Jharkhand and Odisha). Karnataka was the first state to enact its FRBM Act in September 2002, followed by Kerala (2003), Tamil Nadu (2003) and Punjab (2004). Other states also adopted these legislations to avail of the benefits under the incentive scheme recommended by the FC-XII. The adherence to these legislations was also supported by the implementation of Debt Swap Scheme from 2002-2003 to 2004-2005 and Debt Consolidation and Relief Facility from 2005-2006 to 2009-2010 by the central government. These two debt restructuring schemes provided debt relief through debt consolidation, 
Table 2 States' Debt-GSDP/GDP ratio (Average) (in per cent) Source: RBI, various reports of 'State Finances: a Study of Budgets' and authors' calculations

\begin{tabular}{|c|c|c|c|c|c|}
\hline States & $\begin{array}{l}(1981-1982 \text { to } \\
1991-1992)\end{array}$ & $\begin{array}{l}(1992-1993 \text { to } \\
1996-1997)\end{array}$ & $\begin{array}{l}\text { (1997-1998 to } \\
2003-2004)\end{array}$ & $\begin{array}{l}\text { (2004-2005 to } \\
2011-2012)\end{array}$ & $\begin{array}{l}(2012-2013 \\
\text { to } 2015- \\
2016)\end{array}$ \\
\hline 1 & 2 & 3 & 4 & 5 & 6 \\
\hline Andhra Pradesh * & 18.8 & 20.6 & 27.3 & 27.7 & 21.4 \\
\hline Bihar & 42.3 & 53.9 & 56.0 & 43.0 & 25.2 \\
\hline Chhattisgarh & & & 25.5 & 18.5 & 14.5 \\
\hline Goa & 51.5 & 41.4 & 37.1 & 31.0 & 26.3 \\
\hline Gujarat & 17.6 & 19.9 & 30.6 & 30.3 & 23.9 \\
\hline Haryana & 18.6 & 18.7 & 24.6 & 20.8 & 21.6 \\
\hline Jharkhand & & & 23.6 & 25.4 & 23.1 \\
\hline Karnataka & 17.5 & 17.9 & 22.7 & 24.0 & 22.6 \\
\hline Kerala & 14.6 & 23.7 & 31.8 & 33.3 & 31.5 \\
\hline Madhya Pradesh & 27.0 & 27.9 & 29.9 & 33.2 & 22.2 \\
\hline Maharashtra & 14.9 & 15.6 & 23.9 & 25.3 & 19.7 \\
\hline Odisha & 28.3 & 34.4 & 47.5 & 34.2 & 17.6 \\
\hline Punjab & 25.3 & 32.9 & 41.5 & 38.4 & 32.4 \\
\hline Rajasthan & 25.7 & 25.4 & 37.8 & 37.6 & 27.1 \\
\hline Tamil Nadu & 14.0 & 17.4 & 21.9 & 21.9 & 19.6 \\
\hline Uttar Pradesh & 23.8 & 32.9 & 43.6 & 44.8 & 32.8 \\
\hline West Bengal & 19.8 & 23.0 & 36.9 & 45.0 & 35.7 \\
\hline NSC States & 20.7 & 23.3 & 31.2 & 31.3 & 24.5 \\
\hline SC States & 34.1 & 30.1 & 36.7 & 41.9 & 31.7 \\
\hline All States & 18.3 & 20.8 & 26.8 & 26.9 & 22.1 \\
\hline
\end{tabular}

All Ratios pertaining to 'All States' are percentages to GDP. All variables are in nominal terms. NSC and SC refer to non-special and special category states, respectively

*The state of Andhra Pradesh includes the liabilities of newly formed state Telangana

and reduced interest burden on the states. In addition, a turnaround in interest rate cycle also contributed to a gradual reduction in effective interest rates with debt servicing costs declining over time. Reflecting all these developments, the debt position of the state governments improved significantly, as evident from a decline in the average debt-GDP ratio to $22.2 \%$ during 2012-2013 to 2015-2016 from around $31 \%$ in the last decade and a half. This is in line with the FRBM Review Committee (2017) recommendation of targeting debt to GDP ratio of $20 \%$ for the state governments to be achieved by 2023 . However, at a disaggregated level, the debt-GSDP ratio was higher than 30\% in Kerala, Punjab, Uttar Pradesh and West Bengal while it was above $25 \%$ in Bihar, Goa and Rajasthan in the latest period (Table 2). Odisha recorded a remarkable improvement in its debt-GSDP ratio during the period 2004-2005 to 2015-2016. 


\section{Assessment of debt sustainability at the state level in India}

In the empirical literature, there are primarily two approaches to fiscal (debt) sustainability. The first approach looks at various indicators of the sustainability of fiscal policy (Miller 1983; Buiter 1985, 1987; Blanchard 1990; Buiter et al. 1993) while the second approach involves empirical evaluation or tests of government solvency (Hamilton and Glavin 1986; Trehan and Walsh 1988; Bohn 1998). The empirical testing techniques include determination of sustainable (long-run and maximum sustainable) level of public debt based on a partial equilibrium framework, a modelbased approach and signal approach to fiscal sustainability. Marini and Piergallini (2007), however, suggest an integration of the results from these two approaches so as to provide additional information on the issue of government solvency. While indicators are said to be forward looking, tests are considered backward looking as they are based on historical data. It is the stability of the parameters of the primary surplus equation, which in fact determines the usefulness of results derived from indicators or from tests in the assessment of the sustainability of public debt. It is held that "without a systematic break in policy, the predictions of tests are more reliable since the results of indicators are likely to reflect cyclical factors". This paper has used both indicator-based approach and empirical testing techniques for an assessment of debt sustainability at the state level.

\subsection{Indicator-based assessment}

Traditionally, debt sustainability analysis, under indicator-based assessment, takes into account credit-worthiness indicators (nominal debt stock/own current revenue ratio; present value of debt service/own current revenue ratio) and liquidity indicators (debt service/current revenue ratio and interest payments/current revenue ratio). These indicators broadly enable an assessment of the ability of a state government to service its interest payments and repay its debt as and when they become due through current and regular sources of revenues excluding temporary or incidental revenues as grants or capital revenue resulting from sale of assets. Alternatively, debt and debt-service indicators are monitored to assess relationship of existing debt to different types of expenditures or as ratios to various fiscal balances so as to gauge sustainability of both debt and fiscal situation.

An improvement in fiscal conditions creates fiscal space, and enhances debt repayment capacity, while worsening of fiscal conditions entails higher borrowings, adding to the debt burden. In certain situations, the improvement in debt-servicing conditions could also be policy-induced, as discussed in the earlier section. From an analytical point of view, both trends in various fiscal indicators as also characteristics of institutions matter for an assessment of debt sustainability at the state level. In addition, debt sustainability is also associated with a non-financial dimension about the capacity to plan, organise and implement policies, which may be both budget and debt-related.

An analysis based on various indicators of debt sustainability in different phases during the period 1981-1982 to 2015-2016 (Table 3) reveals that the rate of growth 


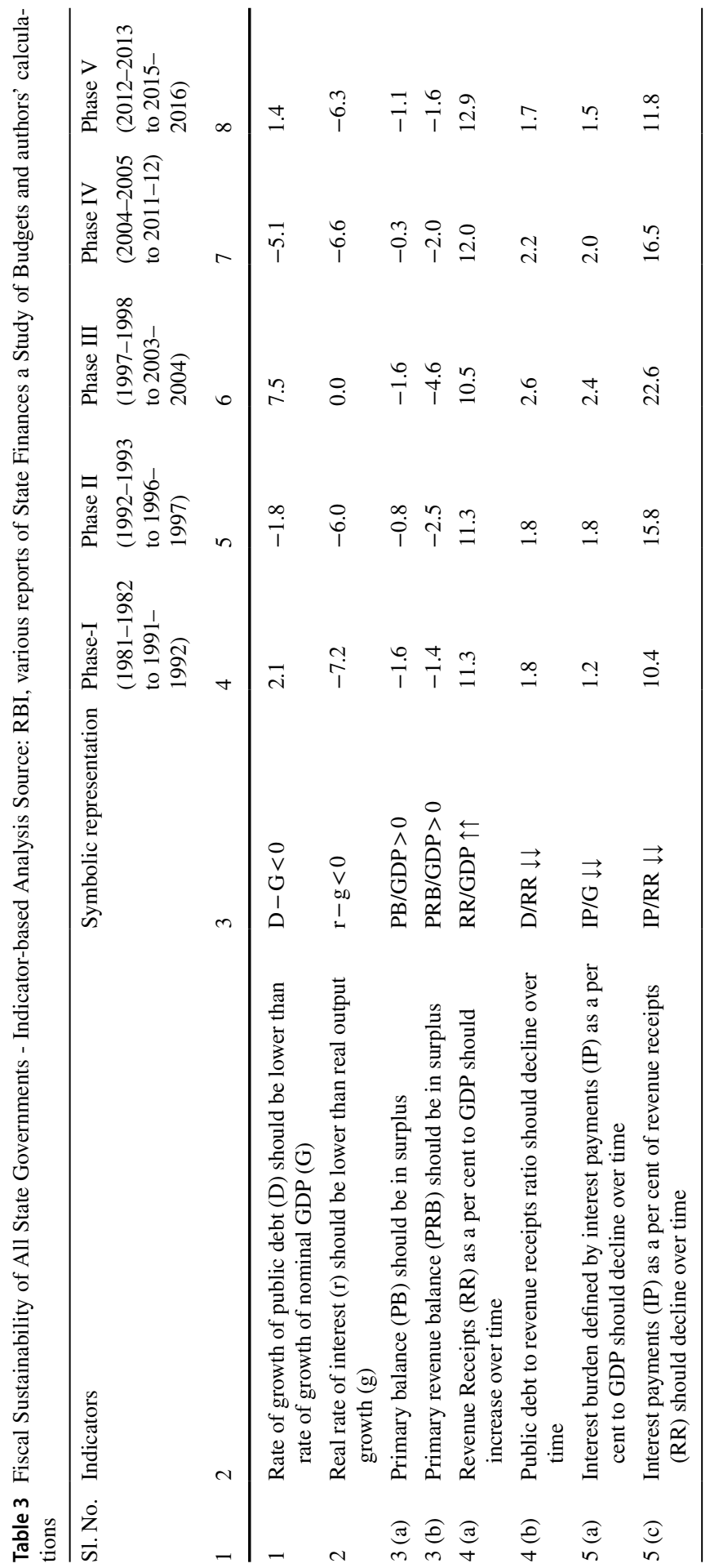




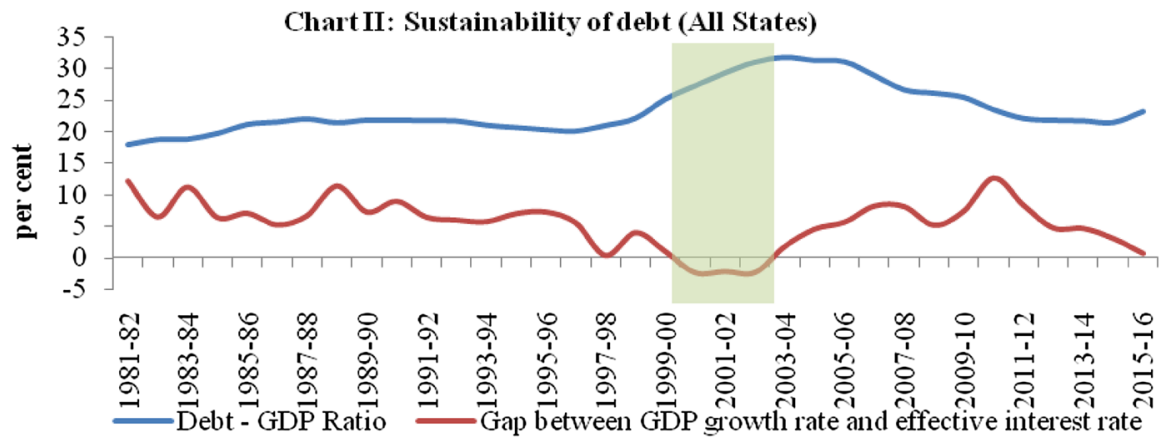

Fig. 2 Sustainability of debt (All States)

of debt of states at the aggregate level exceeded the nominal GDP growth rate during Phase I (1981-1982 to 1991-1992), Phase III (1997-1998 to 2003-2004) and Phase V (2012-2013 to 2015-2016). However, the Domar stability condition that the real rate of interest on debt (i.e., effective interest rate adjusted for inflation) should be lower than the real GDP growth was fulfilled in all the phases except in Phase III when the real rate of interest was almost equal to the real output growth. Here, effective interest rate represents current interest payments as a per cent of outstanding liabilities of state governments in the previous year.

Both primary balance and primary revenue balance remained negative in all the phases, even as there was some improvement in primary revenue balance-GDP ratio in the last two phases. Interest payments (average), which had crossed one-fifth of revenue receipts (considered as a tolerable ratio of interest burden, Dholakia et al. 2004) during Phase III, declined to 16.5 and $11.8 \%$ of revenue receipts in Phase IV and Phase V, respectively.

The trend in debt-GDP ratio of all states was influenced by the differential between the GDP growth and effective interest rate during the period under review (Fig. 2).

A state-wise position in respect of debt sustainability indicators for 17 non-special category states is presented in Table 4 . It may be seen that the rate of growth of GSDP was higher than the effective interest rate in all the states in the last two phases, even as the gap between the two narrowed down in Phase V (Table 4a). Furthermore, the rate of growth of public debt turned out to be higher than the GSDP growth in several states in Phase V, which is a cause of concern (Table 4b). The debt redemption pressure is also evident from the ratio of debt redemption (principal and interest payments) to total debt receipts, which shot up from $64.1 \%$ during 1981-1982 to 2003-2004 to $79.8 \%$ during 2004-2005 to 2015-2016. This is indicative of a smaller proportion of borrowed funds being available for productive uses by the state governments during the latter period.

In addition to the debt sustainability indicators as discussed above, it may also be appropriate to analyse debt profile-linked vulnerability indicators viz., spread on state government debt, average maturity and ownership pattern of debt. These indicators provide an idea about liquidity and pricing risks associated with the level of 
Table 4 Indicators of Debt Sustainability. a Rate of growth of GSDP (g) should be higher than effective interest rate $\mathrm{i} ; \mathrm{g}-\mathrm{i}>0, \mathbf{b}$ Rate of growth of public debt $(\mathrm{k})$ should be lower than growth rate of nominal GSDP (g); $\mathrm{k}-\mathrm{g}<0$ Source: RBI, various reports of State Finances a Study of Budgets and authors' calculations

\begin{tabular}{|c|c|c|c|c|c|}
\hline State & $\begin{array}{l}\text { (1981-1982 to } \\
1991-1992)\end{array}$ & $\begin{array}{l}\text { (1992-1993 to } \\
1996-1997)\end{array}$ & $\begin{array}{l}(1997-1998 \text { to } \\
2003-2004)\end{array}$ & $\begin{array}{l}\text { (2004-2005 to } \\
2011-2012)\end{array}$ & $\begin{array}{l}(2012-2013 \\
\text { to } 2015- \\
2016)\end{array}$ \\
\hline 1 & 2 & 3 & 4 & 5 & 6 \\
\hline \multicolumn{6}{|l|}{$\mathbf{a}$} \\
\hline Andhra Pradesh \$ & 8.4 & 6.3 & -0.5 & 7.6 & 7.7 \\
\hline Bihar & 6.8 & 3.2 & -0.5 & 9.6 & 12.1 \\
\hline Chhattisgarh & & & -0.6 & 9.8 & 6.9 \\
\hline Goa & 9.1 & 12.2 & 5.5 & 11.8 & 1.3 \\
\hline Gujarat & 5.6 & 10.8 & -0.3 & 7.9 & 5.3 \\
\hline Haryana & 7.0 & 4.4 & 0.5 & 8.6 & 5.5 \\
\hline Jharkhand & & & -2.5 & 5.7 & 6.0 \\
\hline Karnataka & 7.3 & 6.4 & -0.7 & 7.5 & 6.1 \\
\hline Kerala & 5.8 & 3.1 & -1.0 & 5.2 & 5.6 \\
\hline Madhya Pradesh & 7.6 & 4.4 & -0.5 & 7.1 & 11.5 \\
\hline Maharashtra & 6.3 & 9.7 & -0.2 & 8.0 & 6.1 \\
\hline Odisha & 5.7 & 2.5 & 1.0 & 8.8 & 5.8 \\
\hline Punjab & 7.8 & 4.5 & -1.4 & 5.5 & 3.9 \\
\hline Rajasthan & 8.1 & 6.6 & -1.4 & 8.3 & 3.6 \\
\hline Tamil Nadu & 7.0 & 7.6 & -1.4 & 8.8 & 7.8 \\
\hline Uttar Pradesh & 6.4 & 4.9 & -2.0 & 7.2 & 5.5 \\
\hline West Bengal & 5.5 & 3.2 & -0.1 & 4.6 & 7.0 \\
\hline NSC States & 6.7 & 7.1 & -0.7 & 7.3 & 6.5 \\
\hline SC States & 7.5 & 6.9 & -0.1 & 6.4 & 7.3 \\
\hline All States & 7.1 & 6.3 & 0.0 & 7.5 & 3.3 \\
\hline \multicolumn{6}{|l|}{$\mathbf{b}$} \\
\hline Andhra Pradesh \$ & 0.9 & 0.5 & 7.4 & -5.2 & -4.3 \\
\hline Bihar & 4.2 & -0.9 & 2.1 & -10.2 & -4.8 \\
\hline Chhattisgarh & & -11.1 & -0.5 & -11.2 & 8.1 \\
\hline Goa & -1.1 & -11.4 & 2.1 & -7.3 & 3.4 \\
\hline Gujarat & 6.9 & -8.3 & 10.5 & -4.4 & -3.0 \\
\hline Haryana & 1.2 & -0.1 & 6.4 & -4.6 & 8.0 \\
\hline Jharkhand & & -9.4 & -6.6 & 2.0 & 2.8 \\
\hline Karnataka & 1.3 & 0.2 & 7.0 & -2.1 & 0.4 \\
\hline Kerala & 3.9 & -0.7 & 9.1 & -1.7 & 0.7 \\
\hline Madhya Pradesh & 2.8 & -1.6 & 3.2 & -4.9 & -7.5 \\
\hline Maharashtra & 5.2 & -3.9 & 10.3 & -4.6 & -4.4 \\
\hline Odisha & 2.9 & 2.1 & 4.9 & -11.9 & -8.0 \\
\hline Punjab & 7.9 & -0.8 & 6.3 & -5.3 & 0.6 \\
\hline Rajasthan & -0.6 & 0.1 & 8.6 & -7.6 & 7.6 \\
\hline Tamil Nadu & 3.1 & -1.1 & 7.8 & -4.7 & -2.5 \\
\hline
\end{tabular}




\begin{tabular}{|c|c|c|c|c|c|}
\hline State & $\begin{array}{l}\text { (1981-1982 to } \\
1991-1992)\end{array}$ & $\begin{array}{l}\text { (1992-1993 to } \\
1996-1997)\end{array}$ & $\begin{array}{l}\text { (1997-1998 to } \\
2003-2004)\end{array}$ & $\begin{array}{l}\text { (2004-2005 to } \\
2011-2012)\end{array}$ & $\begin{array}{l}\text { (2012-2013 } \\
\text { to 2015- } \\
\text { 2016) }\end{array}$ \\
\hline 1 & 2 & 3 & 4 & 5 & 6 \\
\hline Uttar Pradesh & 5.5 & 0.3 & 7.8 & -5.3 & 1.6 \\
\hline West Bengal & 2.4 & 2.3 & 11.4 & -2.2 & -6.1 \\
\hline NSC States & 3.7 & -2.5 & 8.1 & -5.1 & -1.7 \\
\hline SC States & 3.8 & -7.7 & 9.0 & -4.3 & -4.8 \\
\hline All States & 2.1 & -1.8 & 7.5 & -5.1 & 1.4 \\
\hline
\end{tabular}

${ }^{\$}$ The state of Andhra Pradesh includes newly formed state Telangana

All variables are in nominal terms. NSC and SC refer to non-special and special category states, respectively

debt and its composition. From 1988 to 1989 onwards, the weighted average yield on state government securities has been observed to be marginally higher than that on the central government securities. Before this period, these loans were intermediated by the central government. The ownership pattern of state government securities indicates a pre-dominance of commercial banks, although their share in total outstanding state government securities has declined steadily from $78.5 \%$ in end-March 1991 to $61.9 \%$ in end-March 2000 and further to $42.1 \%$ in end-March 2016. The share of insurance companies has, however, increased significantly during the same period. As the state government securities are eligible for being counted towards SLR requirements of banks, investment in these securities is considered credit-risk free. Higher yield on these securities vis-a-vis central government securities is another attraction for long-term investors. The state-specific fiscal performance related risk factors are presumably not being factored in by the investors. However, this situation may not continue for long in case there is any deviation in the extant institutional arrangement for management of state government debt.

\subsection{Econometric framework for assessment of debt sustainability at state level}

The fiscal/debt sustainability exercise, in the empirical literature, is extended beyond the simple indicator-based assessment to validate whether inter-temporal government budget constraint is satisfied. This entails test of stationarity properties of the government debt stock (in level and first difference), examination of the long-term relationship between government revenues and expenditures, between primary balances and debt, and between capital expenditure and public debt (Bhatt 2011). While confirmation of stationarity of government debt stock (in level and first difference) indicates statistical reversion towards mean value after temporary disturbances, the presence of cointegration between government revenues and expenditures reflects their co-movements and anchoring of fiscal imbalances. 


\subsection{Inter-temporal budget constraint}

In line with the empirical literature, we have made an attempt to test whether the fiscal policy stance of Indian states is sustainable, i.e., whether it satisfies the intertemporal budget constraint. This test basically examines whether the past behaviour of state governments' revenues, expenditure and fiscal deficit could be continued indefinitely without prompting an adverse response from the lenders/investors from/ to whom they borrow/sell securities to meet their resource gap.

The inter-temporal budget constraint, under the assumption that the funding of interest payments are not made from the new debt issuances (i.e., no-Ponzi scheme), imposes restrictions on the time series properties of government expenditure and revenues. This requires that government expenditure, revenues and debt stock are all stationary in the first differences. The stationarity property also restricts the extent of deviation of government expenditure from revenues over time. In case government expenditure and revenues are I (1) and cointegrated, then the error correction mechanism would push government finances towards the levels required by the inter-temporal budget constraint and ensure fiscal and debt sustainability in the long term (Olekalns and Cashin 2000).

In this section, to start with, the stationarity properties of state government debt, revenues and expenditure have been tested in a panel data framework. After having done the stationarity test, we have examined whether a long-run equilibrium exists between government expenditure and revenues through panel cointegration tests.

\subsubsection{Data}

All data on state government expenditure, revenues and outstanding level of debt have been taken from the 'Handbook of Statistics of the Indian Economy', published by the Reserve Bank of India. As already mentioned, the data covers the period 1980-1981 to 2015-2016 for 20 Indian states. A list of the states selected for the present analysis is presented in Appendix 1. Only those states have been selected, for which data on all the relevant variables are available for the entire time period. In the case of Bihar, Uttar Pradesh and Madhya Pradesh, the data on respective fiscal variables from 2000 to 2001 also include data relating to Jharkhand, Uttarakhand and Chhattisgarh, respectively. This has been done to ensure comparability of data for the entire period covered in the econometric exercise. The variables have been converted into real terms and logarithmic values of the variables have been considered for the analysis.

\subsubsection{Unit root analysis}

As already mentioned, the stationarity properties of state government debt, revenues and expenditure are tested through panel unit root tests. Panel unit root tests are perceived to be more powerful than the unit root test applied on a single series. This is because the information content of the individual time series gets enhanced by that contained in the cross-section data within a panel set up (Ramirez 2006). There are different methods to carry out panel-based unit root tests. While the panel unit root 
Table 5 Results of panel unit root test

\begin{tabular}{llll}
\hline Variables (Levels) & LLC t Statistics & IPS W Statistics & $\begin{array}{l}\text { Maddala and Wu } \\
\text { PP- Fisher Chi } \\
\text { Square } \\
1\end{array}$ \\
& 2 & & 4 \\
\hline States' Debt (log B) & $-2.86^{*}$ & $-2.19 *$ & 46.95 \\
Government Revenue (log R) & 2.85 & 8.30 & 4.04 \\
Government Expenditure (log G) & 1.63 & 7.90 & 6.39 \\
Variables (Differences) & & & \\
States' Debt (D log B) & $-16.13^{*}$ & $-15.79 *$ & $310.49 *$ \\
Government Revenue (D $\log$ R) & $-27.51^{*}$ & $-28.52^{*}$ & $564.71^{*}$ \\
Government Expenditure (D log G) & $-26.06^{*}$ & $-25.55^{*}$ & $577.12 *$ \\
\hline
\end{tabular}

The statistics are asymptotically distributed as standard normal with a left hand side rejection area. Automatic selection of lags through Schwarz Information Criteria (SIC). All panel unit root tests are defined by Bartlett kernel and Newly West bandwidth

LLC Levin, Lin, Chu (2002), IPS Im, Pesaran, Shin (2003)

*The rejection of the null hypothesis of non-stationarity (LLC, IPS and Maddala \& Wu) at 1 per cent level of significance

methodology of Levin et al. (2002) assumes that there is a common unit root process across the relevant cross sections, the tests suggested by Im et al. (2003) and Maddala and Wu (1999) assume individual unit root processes.

The results of panel unit root tests on relevant fiscal variables (debt, total revenues and total expenditure) are furnished in Table 5. It may be seen that the tests (Levin, Lin and Chu; Im, Pesaran and Shin; and Maddala and Wu) failed to reject the null hypothesis of a unit root for government revenues and expenditure in level form. The tests, however, reject the null of a unit root in the first difference. The government debt, on the other hand, was found to be stationary in level as per the Levin, Lin and Chu and Im, Pesaran and Shin tests. As per the Maddala and Wu test, however, the government debt turned out to be stationary only in the first difference. Overall, the results reveal that the three variables viz, debt, total revenues and total expenditure are stationary in first difference.

\subsubsection{Panel cointegration}

Since $\log R$ and $\log G$ were found to be I (1), in the next step, an attempt has been made to test, whether there exists a long-run equilibrium (steady state) between government expenditure and revenues through the panel cointegration tests. Panel cointegration technique has an advantage over the cointegration tests for individual series as it allows to selectively pool information regarding common long-run relationships from across the panel while allowing the associated short-run dynamics and fixed effects to be heterogeneous across different series of the panel (Pedroni 1999). 
Table 6 Panel cointegration tests for government revenue and expenditure

\begin{tabular}{|c|c|c|}
\hline $\begin{array}{l}\text { Test statistics } \\
1\end{array}$ & $\begin{array}{l}\text { Panel statistics } \\
2\end{array}$ & $\begin{array}{l}\text { Group statistics } \\
3\end{array}$ \\
\hline \multicolumn{3}{|c|}{ Model with no deterministic intercept or trend } \\
\hline V statistics & $12.20 *(0.00)$ & \\
\hline Rho statistics & $-11.16^{*}(0.00)$ & $-8.27 *(0.00)$ \\
\hline PP statistics & $-7.76^{*}(0.00)$ & $-8.90 *(0.00)$ \\
\hline ADF statistics & $-7.45^{*}(0.00)$ & $-8.50 *(0.00)$ \\
\hline \multicolumn{3}{|c|}{ Model with individual intercept and no deterministic trend } \\
\hline V statistics & $9.43 *(0.00)$ & \\
\hline Rho statistics & $-9.90 *(0.00)$ & $-6.87 *(0.00)$ \\
\hline PP statistics & $-8.26^{*}(0.00)$ & $-7.61 *(0.00)$ \\
\hline ADF statistics & $-8.45 *(0.00)$ & $-8.11^{*}(0.00)$ \\
\hline \multicolumn{3}{|c|}{ Model with individual intercept and individual trend } \\
\hline V statistics & $14.46^{*}(0.00)$ & \\
\hline Rho statistics & $-6.63 *(0.00)$ & $-3.83 *(0.00)$ \\
\hline PP statistics & $-6.62 *(0.00)$ & $-6.47 *(0.00)$ \\
\hline ADF statistics & $-6.92 *(0.00)$ & $-6.25^{*}(0.00)$ \\
\hline
\end{tabular}

All reported values are asymptotically distributed as standard normal. Figures in the parentheses indicate the respective $\mathrm{p}$ values. Automatic selection of lags through Schwarz Information Criteria (SIC). Newly West bandwidth selection using a Bartlett kernel

*The rejection of the null hypothesis of no cointegration at 1 per cent level of significance

In this section, the methodology proposed by Pedroni (1999) has been used to test whether a cointegrating relationship exists between government revenues and expenditure of the selected Indian states under study. This method employs four panel statistics and three group panel statistics to test the null hypothesis of no cointegration against the alternative hypothesis of cointegration. In the case of panel statistics, the first-order autoregressive term is assumed to be the same across all the cross sections. On the other hand, in the case of group panel statistics, the parameter is allowed to vary over the cross sections. The statistics are distributed, in the limit, as standard normal variables with a left hand rejection region, with the exception of variance ratio statistics. The results of the cointegration tests are presented in Table 6.

The test results for both the panel and group statistics reveal strong evidence of panel cointegration. The estimated 'rho' statistics, variance ratio ' $V$ ' statistics, Augmented Dickey Fuller 't' statistics and the Phillips and Perron (non-parametric) ' $t$ ' statistics reject the null hypothesis of no cointegration at $1 \%$ level for all the three models: (i) model with no deterministic intercept or trend; (ii) model with individual intercept and no deterministic trend; and (iii) model with individual intercept and individual trend. This implies that the cointegration results are not affected by different modelling assumptions.

The results of the Pedroni test are also supported by Kao residual cointegration test, which rejects the null hypothesis of no cointegration at $1 \%$ level (Table 7). 
Table 7 Results of Kao residual panel cointegration tests

\begin{tabular}{lll}
\hline Item & t-Statistic & $\begin{array}{l}\text { Prob. } \\
1\end{array}$ \\
\hline ADF & 2 & 3 \\
Residual variance & $-12.72^{*}$ & 0.00 \\
HAC variance & 0.006 & \\
\hline
\end{tabular}

Newly West bandwidth selection using a Bartlett kernel. Automatic selection of lags through Schwarz Information Criteria

*The rejection of the null hypothesis of no cointegration at $1 \%$ level of significance

Thus, the overall findings of the panel cointegration tests reveal that the two series, government revenues and expenditure are cointegrated, indicating a long-term comovement between them. The results suggest that the current fiscal position of Indian states is sustainable in the long run.

\subsection{Fiscal policy response function}

Bohn (1998), Adams et al. (2010) and Tiwari (2012) have analysed the response of primary surplus to variations in public debt for the purpose of assessment of fiscal policy/debt sustainability. In case primary surplus (relative to GDP) is observed to be a positive function of public debt (relative to GDP), it implies that rising debt ratios lead to higher primary surpluses relative to GDP, which is indicative of a tendency towards mean reversion and thus fiscal/debt sustainability. We have also used this approach in the following analysis.

\subsubsection{Model specification}

The following equation is estimated in a panel data framework with annual data from 1980-1981 to 2015-2016.

$$
\mathrm{S}_{\mathrm{t}}=\alpha_{0}+\beta \mathrm{D}_{(\mathrm{t}-1)}+\alpha_{1} \mathrm{GSDPGAP}_{\mathrm{t}}+\alpha_{2} \mathrm{EXPGAP}_{\mathrm{t}}+\varepsilon
$$

In this equation, GSDP is the gross state domestic product; $\mathrm{S}$ is the primary balance to GSDP ratio; D is debt to GSDP ratio; GSDPGAP is the deviation of actual output from the trend; EXPGAP is the deviation of actual primary expenditure from the trend; $\varepsilon$ is the error term. The business cycle variable GSDPGAP has been included to account for the fluctuations in revenues. The variable EXPGAP captures the impact of deviations of real primary expenditure from its long-term trend on the primary balance ratio. Here ' $\beta$ ' is the key coefficient, which measures the response of primary balance to debt. A value of this coefficient between zero and unity is consistent with a sustainable fiscal policy response to debt. A negative coefficient implies potentially destabilising response. In addition, allowance has been made in the estimations for the response of primary balance to GSDP ratio to be non-linear and vary with debt levels by introducing a square term of the debt to GSDP ratio as an additional explanatory variable. 
Table 8 Results of panel unit root tests

\begin{tabular}{lll}
\hline Variables (Levels) & LLC t Statistics & IPS W Statistics \\
1 & 2 & 3 \\
\hline States' Debt/GSDP & $-2.34^{*}$ & $-2.25^{*}$ \\
Primary Surplus/GSDP & $-7.16^{*}$ & $-8.30^{*}$ \\
GSDPGAP & $-7.00^{*}$ & $-11.17^{*}$ \\
EXPGAP & $-11.71^{*}$ & $-13.29^{*}$ \\
\hline
\end{tabular}

Automatic selection of lags through Schwarz Information Criteria (SIC). All panel unit root tests are defined by Bartlett kernel and Newly West bandwidth

LLC Levin, Lin, Chu (2002), IPS Im, Pesaran, Shin (2003)

$*$ The rejection of the null hypothesis of non-stationarity at 1 per cent level of significance

\subsubsection{Data}

As in the earlier empirical exercise, the fiscal policy response function has also been estimated for 20 states, for which data on all the relevant variables are available for the period 1980-1981 to 2015-2016. The data for Bihar, Uttar Pradesh and Madhya Pradesh from 2000 to 2001 also include that relating to Jharkhand, Uttarakhand and Chhattisgarh, respectively. Outstanding liabilities of each state government have been used to represent the level of their debt. GSDPGAP for each state has been worked out by extracting the deviation in real GSDP from its trend through HPFilter. The deviation is expressed as a per cent of real GSDP. EXPGAP has been calculated in a similar manner using real primary expenditure of the state governments. The pair-wise correlation coefficients between the explanatory variables were found to be statistically insignificant, thus ruling out any multicollinearity problem.

\subsubsection{Results}

Before proceeding with the estimation, all the series were tested for stationarity. Based on panel unit root tests involving common unit root process (LLC) as well as individual unit root process (IPS), the dependent variable and the explanatory variable series were found to be stationary, i.e., I (0). The results of the panel unit root tests are furnished in Table 8.

To decide on the panel models, i.e., whether it is a fixed effect (FE) model or a random effect (RE) model, Hausman test was conducted for each of the two model specifications (linear and non-linear). The summary results of the Hausman test are furnished in Appendix 2. The results of the Hausman test for both the models indicate that there is a significant difference in the coefficients estimated by the FE and RE models. Therefore, the null hypothesis of correlated random effect is rejected and the alternative hypothesis that individual specific effect is correlated with the explanatory variables is accepted. Accordingly, fixed effect model has been chosen for estimating the two model specifications indicated above. 
Table 9 Estimation results

\begin{tabular}{lll}
\hline Explanatory variables & \multicolumn{2}{l}{ Estimated coefficients } \\
\cline { 2 - 3 } & Model 1 (Linear) & Model 2 (Non-linear) \\
& 2 & 3 \\
\hline Constant & $-2.78^{*}$ & $-3.77^{*}$ \\
& $(0.00)$ & $(0.00)$ \\
$\mathrm{D}_{\mathrm{t}-1}$ & $0.05^{*}$ & $0.11^{*}$ \\
& $(0.00)$ & $(0.00)$ \\
$\mathrm{D}_{\mathrm{t}-1}^{2}$ & & $-0.001^{* *}$ \\
& & $(0.03)$ \\
GSDPGAP & $0.04^{*}$ & $0.04^{*}$ \\
& $(0.00)$ & $(0.00)$ \\
EXPGAP & $-0.10^{*}$ & $-0.10^{*}$ \\
& $(0.00)$ & $(0.00)$ \\
AR $(1)$ & $0.50^{*}$ & $0.50^{*}$ \\
Adjusted $\mathrm{R}^{2}$ & $(0.00)$ & $(0.00)$ \\
DW & 0.76 & 0.78 \\
\hline
\end{tabular}

Figures in the parentheses represent respective $\mathrm{P}$ values

*Significant at $1 \%$ level; **significant at $5 \%$ level

The models have been estimated through generalised least square technique with cross section Seemingly Unrelated Regression (SUR) with a correction for first order autoregressive error term. The models are adjusted for the heteroscedasticity with White cross-section standard errors and covariance method. The empirical results from the panel regression exercise are presented in Table 9. In Model 1 (linear model), the coefficients of all the explanatory variables were found to be significant at one per cent level. Positive coefficient of D indicates that the primary balance of state governments increases in response to rising debt ratios. This implies that the primary fiscal balance in India responds in a stabilising manner to increases in debt. Positive coefficient of GSDPGAP implies that primary balance improves when GSDP is above the trend. The negative coefficient of EXPGAP, on the other hand, indicates that the primary balance declines when primary expenditure is above the trend. These findings are in line with a priori expectations.

In the non-linear equation approach (Model 2), allowance was made for the possibility that the response of the primary balance to debt is better represented in terms of a quadratic function rather than a linear response function. The results suggest that the primary balance function has an inverted ' $u$ ' shape, implying that the adjustment parameter first rises and then falls. 


\section{Going beyond the conventional debt sustainability analysis}

In the empirical literature, several studies have gone beyond the conventional debt sustainability analysis in various ways. This has been done by extending the scope of conventional debt analysis (based on the inter-temporal budget constraint in a static environment) to account for fiscal and economic behaviour in response to shocks (sensitivity analysis), fiscal vulnerabilities (stress-testing exercise) and short-term refinancing risks. The interaction of key variables driving debt dynamics is also factored in debt sustainability exercises. There are other studies which have used a more comprehensive concept of debt, covering not only explicit liabilities but also contingent, implicit and off-budget liabilities.

After having examined the debt sustainability issue, based on indicator-based approach, inter-temporal budget constraint exercise and fiscal policy response function of states in the earlier sections, an attempt has been made to examine the impact of contingent liabilities on debt/fiscal sustainability of states in India. Article 293 (1) of the Constitution of India provides that a state government can give guarantees within such limits as may be fixed by the state legislature on the security of the Consolidated Fund of the State. Guarantees issued by states are considered as contingent liabilities on the Consolidated Fund of the State in case of default by the borrower for whom the guarantee is extended. The state governments have generally been conservative in the issuance of guarantees (in respect of loans raised by government departments, public sector undertakings, local authorities, statutory boards and corporations, and co-operative institutions) and follow certain norms, whether stipulated under the State Government Guarantees Act or FRBM Acts/FRLs of states or administrative limits fixed for issuance of guarantees. Under these enactments, limits are fixed on annual incremental guarantees as ratio to GSDP or total revenue receipts (Appendix 3). Apart from the differences across states in terms of guidelines relating to guarantees, there are also sharp differences when it comes to awareness about fiscal risk linked to issuance of these guarantees and the state level efforts to reduce outstanding guarantees as a policy initiative.

The guarantee commitments of state governments in respect of state public sector enterprises (SPSEs) have recently emerged as a major source of potential risk to fiscal and debt sustainability at the state level. While the need for issuance of guarantees to SPSEs arose after 1993-1994, when the practice of allocation of a separate share in market borrowings to these enterprises was discontinued, it assumed further importance in the wake of declining budgetary support to these enterprises for meeting their capital requirements. As borrowing requirements of these entities increased, these were backed by issuance of guarantees in several states, resulting in an increase in explicit contingent liabilities of these states. This problem is more acute in those states, which have not enacted any law or framed any rules for fixing the ceiling on guarantees to be given by the state government. On the other hand, there are a few states (Odisha) which have exercised due precaution in putting in place rules to avoid the spill-over effect of these guarantees to state budgets.

The unbridled growth in guarantees issued to SPSEs, which have large outstanding debt and are also incurring losses, have increased vulnerability of these 
Table 10 Outstanding debt, guarantees and accumulated profit/losses of state PSUs in-end march 2015 (Amount in crore) Source: Comptroller and Auditor General of India (CAG)

\begin{tabular}{|c|c|c|c|}
\hline State & Outstanding debt & $\begin{array}{l}\text { Outstanding guar- } \\
\text { antees }\end{array}$ & Accumulated profit/loss \\
\hline 1 & 2 & 3 & 4 \\
\hline Andhra Pradesh & $52,983.6$ & 7581.34 & $-10,812.19$ \\
\hline Assam & 2783.52 & Nil & -3658.21 \\
\hline Bihar & $11,693.27$ & 3732.97 & -3137.76 \\
\hline Chhattisgarh & $13,602.11$ & 744.73 & -4780.58 \\
\hline Gujarat & $42,509.05$ & 1652.82 & 3721.00 \\
\hline Haryana & $37,847.90$ & $28,746.85$ & $-24,043.86$ \\
\hline Himachal Pradesh & 6568.11 & 2746.24 & -2951.26 \\
\hline Jammu \& Kashmir & 4429.09 & 2574.78 & -2907.29 \\
\hline Jharkhand & 7736.75 & Nil & $-16,755.73$ \\
\hline Karnataka & $32,086.94$ & 7251.35 & 731.66 \\
\hline Kerala & 8912.96 & 5579.21 & -198.94 \\
\hline Madhya Pradesh & $37,178.92$ & 8958.90 & $-29,597.25$ \\
\hline Maharashtra & $54,477.66$ & 2540.30 & -9071.83 \\
\hline Manipur & 3.05 & Nil & -74.74 \\
\hline Meghalaya & 1310.44 & 758.18 & -576.93 \\
\hline Mizoram & 30.93 & 18.61 & -58.03 \\
\hline Nagaland & 61.66 & 15.00 & -49.35 \\
\hline Odisha & 7503.98 & 2001.37 & 2763.57 \\
\hline Punjab & $14,597.07$ & $49,058.42$ & -6236.66 \\
\hline Rajasthan & $74,747.68$ & $90,054.11$ & $-83,732.89$ \\
\hline Sikkim & 273.25 & 109.50 & -117.72 \\
\hline Tamil Nadu & $62,044.08$ & $16,951.26$ & $-38,233.61$ \\
\hline Telangana & $50,969.43$ & $15,249.51$ & $-15,343.59$ \\
\hline Tripura & 245.56 & Nil & -634.48 \\
\hline Uttar Pradesh & $88,850.29$ & $59,822.93$ & $-94,151.70$ \\
\hline West Bengal & $23,604.19$ & 8060.49 & -190.07 \\
\hline
\end{tabular}

Data relating to Odisha, Mizoram and Nagaland pertain to 2013-2014 and those relating to Tamil Nadu to the year 2012-2013

enterprises with fiscal implications for the state governments. This is evident from the data relating to outstanding debt and accumulated losses/profit of SPSEs in endMarch 2015 (Table 10). In some states, the outstanding debt of SPSEs is of much larger magnitude than outstanding guarantees issued to these undertakings. On top of this, many SPSEs have accumulated huge losses, which indicate their poor debtservicing capacity, entailing the risk of default in future.

A state-wise picture of outstanding liabilities and guarantee commitments including guarantees issued to power sector companies is given in Appendix 4. While the guarantees outstanding as a per cent of outstanding liabilities of all states was around $16.1 \%$ in end-March 2015, it exceeded the all-states average in seven states. Power 
sector's share was the largest in total guarantees outstanding, with power sector in seven states having a share of more than $80 \%$. In fact, the fiscal risk associated with guarantees issued to power sector has repeatedly been experienced since the early 2000s. In 2001, the burden of outstanding dues of state electricity boards to central public sector undertakings was taken over by state governments through issuance of power bonds amounting to Rs. 29,606 crore. The accumulated losses of all power distribution utilities (DISCOM) were estimated at Rs. 1.90 lakh crore as on March 31, 2011 (Expert Group on Financial Health of State Distribution Utilities; Chairman: Shri B K Chaturvedi), requiring another financial restructuring plan (FRP) (October 5, 2012) involving take over of outstanding short-term loans as of March 31,2012 to the extent of $50 \%$ by the respective states under this plan. However, the accumulated losses of DISCOMs in the country increased further to approximately Rs. 3.8 lakh crore as on March 31, 2015, despite the implementation of FRP in select states where the situation was critical. In 2015-2016, the central government announced a new Scheme viz, Ujwal Discom Assurance Yojana (UDAY) for the purpose of financial and operational restructuring of the state power distribution companies (DISCOMs). 16 states $^{1}$ have signed MoUs to take over $75 \%$ of outstanding debt of their DISCOMs under the UDAY over a period of 2 years (and in some cases in 5 years) adding to their liabilities and involving additional interest expenditure over a period of 10 years (Appendix 5). Furthermore, these states are also expected to fund the future losses, if any, of DISCOMs in a graded manner and this liability could be as high as $50 \%$ of the previous year's loss in the year 2020-2021. These states have issued bonds to the tune of Rs. 2.32 lakh crore, i.e., around $54 \%$ of total outstanding debt of DISCOMs, estimated at Rs. 4.3 lakh crore as at end-September 2015. It is, therefore, imperative that the underlying operational efficiency parameters ${ }^{2}$ are achieved within the stipulated time frame to bring about a turnaround in financial position of DISCOMs, and to avoid state government participation in such restructuring exercises in future, which may assume crisis proportion.

Majority of the states are yet to implement the recommendation of the Group of State Finance Secretaries on the Fiscal Risk on State Government Guarantees (2002) that appropriate risk weights be assigned to guarantees given by states on the basis of probability of devolvement of guarantees, and adequate budgetary provisions be made for honouring these guarantees in case they devolve on the states. The Group had in fact gone a step further by recommending that "guarantees in regard to liabilities which are clearly intended to be met out of budgetary resources should be treated as equivalent to debt." In case, we take outstanding liabilities of states along with their PSUs, the position of some states turns out to be quite alarming on the back of accumulation of losses of PSUs in these states (Appendix 6).

\footnotetext{
1 In addition, 6 states have signed MoUs to bring about an improvement in operational efficiency of their DISCOMs.

2 These include reduction of AT \& C loss to $15 \%$ by $2018-2019$; reduction in gap between average revenue realised and average cost of supply of power to zero by 2018-2019; and almost all DISCOMs to be profitable by $2017-2018$ and 3-4 by 2018-2019.
} 


\section{Conclusion}

In this paper, the debt sustainability of state governments in India was assessed through indicator-based analysis as well as empirical exercises. The indicator-based analysis revealed that while most of the debt sustainability indicators showed significant improvement during 2004-2005 to 2015-2016 compared to the earlier phase (1997-1998 to 2003-2004), debt repayment capacity and interest burden indicators lagged behind their respective performance levels achieved during 1981-1982 to 1991-1992.

The estimation results based on a panel data framework covering 20 Indian states for the time period 1980-1981 to 2015-2016 revealed that there is a cointegrating relationship between government revenues and expenditure in India, which tantamount to satisfying the inter-temporal budget constraint. Moreover, the estimated fiscal policy response function showed that the primary balance position of Indian states responds in a stabilising manner to the increases in debt levels. Thus, both the results indicate that the current debt situation at the state level is sustainable in the long run.

Disaggregated level analysis, however, revealed that despite an overall improvement in debt position of the Indian states, some of the states have not been able to achieve their respective FC-XIII targets. Going forward, there are several developments with a bearing on debt/fiscal sustainability of states in India. First, the committed liabilities of states may increase in case they decide to implement the Seventh Pay Commission Award, even as some of them have their own pay panels. Second, the interest liabilities of states that have participated in financial restructuring of DISCOMs would increase besides additional provision to be made by them for extending financial support to these utilities in case they continue to incur losses in future as spelled out in MoUs signed by them. Third, the guarantees given to other SPSEs in some states, which are also loss-making entities, could also give rise to financial burden on the states. These dimensions would assume importance in case there is any deviation from the extant institutional arrangement for management of state government debt.

Overall, the conventional debt sustainability analysis, as attempted in this paper, shows that debt position of states at the aggregate level is sustainable. While we have not analysed the implicit liabilities (linked to PPP projects and unfunded liabilities related to pension), our paper highlights that the explicit contingent liabilities linked to guarantees given by the state governments have assumed significance in the context of debt sustainability exercise at the state level. Given this, any debt/fiscal sustainability exercise, based only on outstanding liabilities of states does not provide a realistic assessment of the situation at the individual state level. We would like to conclude with an observation of the RBI Group which was set up to assess the fiscal risk of State Government Guarantees (2002) that

"in order to have a norm in terms of debt sustainability the underlying guarantees can be mapped out and likely amount of devolvement could be estimated for future years. The total of such likely devolvement during the 
life of the guarantees could then be treated as normal debt and clubbed together with debt obligations. Together, the liability could be measured as a ratio of SDP to ensure that debt plus likely devolvement on guarantees during its life is sustainable and to ensure that guarantees are also captured in such measures".

Acknowledgements The authors would like to thank Shri Indranil Bhattacharyya for his valuable suggestions and comments. The views expressed in the paper are those of the authors and do not necessarily reflect the views of the Reserve Bank of India.

Open Access This article is distributed under the terms of the Creative Commons Attribution 4.0 International License (http://creativecommons.org/licenses/by/4.0/), which permits unrestricted use, distribution, and reproduction in any medium, provided you give appropriate credit to the original author(s) and the source, provide a link to the Creative Commons license, and indicate if changes were made.

\section{Appendix 1: List of States}

1. Andhra Pradesh

2. Assam

3. Bihar

4. Gujarat

5. Haryana

6. Himachal Pradesh

7. Jammu \& Kashmir

8. Karnataka

9. Kerala

10. Maharashtra

11. Manipur

12. Meghalaya

13. Madhya Pradesh

14. Odisha

15. Punjab

16. Rajasthan

17. Tamil Nadu

18. Tripura

19. Uttar Pradesh

20. West Bengal

\section{Appendix 2: Results of the Hausman test for correlated random effects}

\begin{tabular}{llll}
\hline Test summary & Chi-Sq. Statistic & Chi-Sq. d.f. & Prob. \\
\hline
\end{tabular}

Model 1 


\begin{tabular}{llll}
\hline Test summary & Chi-Sq. Statistic & Chi-Sq. d.f. & Prob. \\
\hline $\begin{array}{l}\text { Cross-section random } \\
\text { Model 2 }\end{array}$ & 49.43 & 3 & 0.00 \\
Cross-section random & 53.28 & 4 & 0.00 \\
\hline
\end{tabular}

\section{Appendix 3: Limits on guarantee set in fiscal responsibility and budget management acts* or other legislations of states}

Source: FRBM Acts of respective state governments and Comptroller and Auditor General of India

\begin{tabular}{|c|c|c|c|}
\hline \multirow[t]{2}{*}{ State } & \multicolumn{3}{|l|}{ Guarantees } \\
\hline & Act & Stipulated limits & $\begin{array}{l}\text { Guarantee redemption } \\
\text { Fund }(\mathrm{GRF})^{\mathrm{a}}\end{array}$ \\
\hline Andhra Pradesh & $\begin{array}{l}\text { Andhra Pradesh FRBM } \\
\text { Act, } 2005\end{array}$ & $\begin{array}{l}\text { The amount of annual } \\
\text { incremental risk } \\
\text { weighted guarantees } \\
\text { to be limited to } 90 \text { per } \\
\text { cent of the total revenue } \\
\text { receipts in the year pre- } \\
\text { ceding the current year }\end{array}$ & GRF set up in $2002-2003$ \\
\hline Arunachal Pradesh & $\begin{array}{r}\text { Arunachal Pradesh } \\
\text { FRBM Act, } 2006\end{array}$ & $\begin{array}{l}\text { The State to be con- } \\
\text { servative in giving } \\
\text { guarantees }\end{array}$ & GRF not yet set up \\
\hline Assam & $\begin{array}{l}\text { Administrative ceiling } \\
\quad(2000) \\
\text { Assam FRBM Act, } 2005\end{array}$ & $\begin{array}{l}\text { The ceiling on guarantee } \\
\text { issued by the state } \\
\text { government was fixed } \\
\text { at Rs. } 1500 \text { crore } \\
\text { As per the FRBM Act, } \\
\text { Government guarantees } \\
\text { to be restricted at any } \\
\text { point of time to } 50 \text { per } \\
\text { cent of State's own tax } \\
\text { and non-tax revenues } \\
\text { of the second preceding } \\
\text { year, as reflected in } \\
\text { the books of accounts } \\
\text { maintained by the } \\
\text { Accountant General }\end{array}$ & $\begin{array}{l}\text { GRF created vide notifica- } \\
\text { tion dated September } 15 \text {, } \\
2009\end{array}$ \\
\hline Bihar & Bihar FRBM Act, 2006 & $\begin{array}{l}\text { No stipulation relating to } \\
\text { guarantees in the Act }\end{array}$ & GRF not yet set up \\
\hline Chhattisgarh & $\begin{array}{l}\text { Chhattisgarh FRBM Act, } \\
2006\end{array}$ & $\begin{array}{l}\text { Outstanding guarantees } \\
\text { at the end of the year } \\
\text { should not exceed } 1.5 \\
\text { per cent of GSDP }\end{array}$ & GRF not yet set up \\
\hline
\end{tabular}




\begin{tabular}{|c|c|c|c|}
\hline \multirow[t]{2}{*}{ State } & \multicolumn{3}{|l|}{ Guarantees } \\
\hline & Act & Stipulated limits & $\begin{array}{l}\text { Guarantee redemption } \\
\text { Fund }(\mathrm{GRF})^{\mathrm{a}}\end{array}$ \\
\hline Goa & $\begin{array}{l}\text { The Goa State Guarantees } \\
\text { Act, } 1993\end{array}$ & $\begin{array}{l}\text { The Government should } \\
\text { cap the total outstand- } \\
\text { ing guarantees within } \\
\text { the specified limit } \\
\text { under the Goa State } \\
\text { Guarantees Act, } 1993 \text {. } \\
\text { The Goa legislature had } \\
\text { fixed a limit of Rs. } 800 \\
\text { crore on the outstanding } \\
\text { guarantees in March } \\
\text { 2005. }\end{array}$ & $\begin{array}{l}\text { Set up GRF during } \\
\text { 2003-2004 }\end{array}$ \\
\hline Gujarat & $\begin{array}{l}\text { The Gujarat Sate Guaran- } \\
\text { tees Act, } 1963\end{array}$ & $\begin{array}{l}\text { The Government should } \\
\text { cap the total outstand- } \\
\text { ing guarantees within } \\
\text { the limit provided in the } \\
\text { Gujarat Sate Guaran- } \\
\text { tees Act, 1963. The } \\
\text { state legislature decides } \\
\text { such limits from time to } \\
\text { time. With effect from } \\
\text { March } 2001 \text {, the limit } \\
\text { for the total outstand- } \\
\text { ing guarantees is Rs. } \\
20,000 \text { crore }\end{array}$ & Set up GRF in 1963 \\
\hline Haryana & $\begin{array}{l}\text { Haryana FRBM Act, } \\
2005\end{array}$ & $\begin{array}{l}\text { Does not contain any } \\
\text { provisions for limiting } \\
\text { the guarantees given by } \\
\text { the state government }\end{array}$ & GRF set up in July 2003 \\
\hline Himachal Pradesh & $\begin{array}{l}\text { Himachal Pradesh FRBM } \\
\text { Act, } 2005\end{array}$ & $\begin{array}{l}\text { The total outstanding } \\
\text { guarantees should be } \\
\text { limited to } 40 \text { per cent } \\
\text { of revenue receipts for } \\
\text { the year preceding the } \\
\text { current year }\end{array}$ & GRF not yet set up \\
\hline Jammu \& Kashmir & $\begin{array}{r}\text { Jammu \& Kashmir } \\
\text { FRBM Act, } 2006\end{array}$ & $\begin{array}{l}\text { The Act limits the } \\
\text { amount of annual incre- } \\
\text { mental risk weighted } \\
\text { guarantees to } 75 \text { per } \\
\text { cent of the total revenue } \\
\text { receipts in the year } \\
\text { preceding the current } \\
\text { year or at } 7.5 \text { per cent } \\
\text { of GSDP of the year } \\
\text { preceding the current } \\
\text { year, whichever is lower }\end{array}$ & $\begin{array}{l}\text { GRF set up vide order } \\
\text { dated August 22, } 2006\end{array}$ \\
\hline Jharkhand & $\begin{array}{l}\text { Jharkhand FRBM Act } \\
2007\end{array}$ & $\begin{array}{l}\text { No guarantee policy has } \\
\text { been framed }\end{array}$ & GRF not yet set up \\
\hline
\end{tabular}




\begin{tabular}{|c|c|c|c|}
\hline \multirow[t]{2}{*}{ State } & \multicolumn{3}{|l|}{ Guarantees } \\
\hline & Act & Stipulated limits & $\begin{array}{l}\text { Guarantee redemption } \\
\text { Fund }(\mathrm{GRF})^{\mathrm{a}}\end{array}$ \\
\hline Karnataka & $\begin{array}{l}\text { The Karnataka Ceiling to } \\
\text { Government Guarantees } \\
\text { Act, } 1999 \\
\text { The Karnataka Fiscal } \\
\text { Responsibility Act, } \\
2002\end{array}$ & $\begin{array}{l}\text { The Act prescribes that } \\
\text { the total outstand- } \\
\text { ing guarantees as on } \\
\text { April } 1 \text { of any year } \\
\text { shall not exceed eighty } \\
\text { per cent of the state's } \\
\text { revenue receipts of the } \\
\text { second preceding year } \\
\text { as in the books of the } \\
\text { Accountant General of } \\
\text { Karnataka } \\
\text { Under the Fiscal Res- } \\
\text { posibility Act, the state } \\
\text { government is required } \\
\text { not to give guarantee } \\
\text { for any amount exceed- } \\
\text { ing the limit stipulated } \\
\text { under the Karnataka } \\
\text { Ceiling to Government } \\
\text { Guarantees Act, } 1999\end{array}$ & $\begin{array}{l}\text { The state government } \\
\text { had set up a 'Guarantee } \\
\text { Reserve Fund' during } \\
\text { 1999-2000. However, it } \\
\text { is yet to constitute a GRF }\end{array}$ \\
\hline Kerala & $\begin{array}{l}\text { The Kerala Ceiling on } \\
\text { Government Guarantees } \\
\text { Act, } 2003\end{array}$ & $\begin{array}{l}\text { Under the Act, the Gov- } \\
\text { ernment guarantees as } \\
\text { on the 1st day of April } \\
\text { of any year shall not } \\
\text { exceed Rs. } 14,000 \text { crore }\end{array}$ & GRF not yet set up \\
\hline Madhya Pradesh & $\begin{array}{l}\text { Madhya Pradesh FRBM } \\
\text { Act, } 2005\end{array}$ & $\begin{array}{l}\text { The state government } \\
\text { shall limit the annual } \\
\text { incremental guarantees } \\
\text { so as to ensure that } \\
\text { the total guarantees do } \\
\text { not exceed } 80 \text { per cent } \\
\text { of the total revenue } \\
\text { receipts in the year pre- } \\
\text { ceding the current year }\end{array}$ & GRF set up in January 2006 \\
\hline Maharashtra & $\begin{array}{l}\text { Maharashtra FRBM Act, } \\
2005\end{array}$ & $\begin{array}{l}\text { The Act does not contain } \\
\text { any provision for } \\
\text { limiting the guaran- } \\
\text { tees given by the state } \\
\text { government }\end{array}$ & GRF not yet set up \\
\hline Manipur & $\begin{array}{l}\text { The Manipur Ceiling } \\
\text { on State Government } \\
\text { Guarantees Act, } 2004\end{array}$ & $\begin{array}{l}\text { Under the Act, the total } \\
\text { outstanding Govern- } \\
\text { ment Guarantees as on } \\
\text { the first day of April } \\
\text { of any year shall not } \\
\text { exceed thrice the state's } \\
\text { Own Tax revenue } \\
\text { receipts of the second } \\
\text { preceding year as they } \\
\text { stood in the books of } \\
\text { the Accountant General } \\
\text { of Manipur }\end{array}$ & GRF set up in 2008-2009 \\
\hline
\end{tabular}




\begin{tabular}{|c|c|c|c|}
\hline \multirow[t]{2}{*}{ State } & \multicolumn{3}{|l|}{ Guarantees } \\
\hline & Act & Stipulated limits & $\begin{array}{l}\text { Guarantee redemption } \\
\text { Fund }(\mathrm{GRF})^{\mathrm{a}}\end{array}$ \\
\hline$\overline{\text { Meghalaya }}$ & $\begin{array}{l}\text { Meghalaya FRBM Act, } \\
2006\end{array}$ & $\begin{array}{l}\text { There is no statutory limit } \\
\text { as to the outstanding } \\
\text { amount of contingent } \\
\text { liabilities. However, the } \\
\text { state is committed to } \\
\text { restricting the issue of } \\
\text { guarantees }\end{array}$ & GRF set up in 2014-2015 \\
\hline Mizoram & $\begin{array}{l}\text { The Mizoram Ceiling on } \\
\text { Government Guarantees } \\
\text { Act, } 2011\end{array}$ & $\begin{array}{l}\text { The total outstanding } \\
\text { government guarantees } \\
\text { as on the first day of } \\
\text { April of any year shall } \\
\text { not exceed } 25 \text { per cent } \\
\text { of the GSDP estimated } \\
\text { for the year and fresh } \\
\text { guarantees given in a } \\
\text { year shall not exceed } \\
3 \text { per cent of GSDP } \\
\text { estimated for the year }\end{array}$ & GRF set up in May 2009 \\
\hline Nagaland & $\begin{array}{l}\text { Nagaland FRBM Act, } \\
2005\end{array}$ & $\begin{array}{l}\text { The Act limits the } \\
\text { amount of annual incre- } \\
\text { mental risk weighted } \\
\text { guarantees to } 1 \text { per } \\
\text { cent of total revenue } \\
\text { receipts or } 1 \text { per cent of } \\
\text { the estimated GSDP in } \\
\text { the year preceding the } \\
\text { current year, whichever } \\
\text { is lower. The exercise } \\
\text { on risk-weighting of the } \\
\text { guarantees not yet done }\end{array}$ & GRF set up in 2006-2007 \\
\hline Odisha & $\begin{array}{l}\text { Administrative ceiling } \\
\text { on guarantees fixed in } \\
\text { November } 2002\end{array}$ & $\begin{array}{l}\text { In terms of the adminis- } \\
\text { trative ceiling, the total } \\
\text { outstanding guarantees } \\
\text { as on 1st day of April } \\
\text { every year shall not } \\
\text { exceed } 100 \text { per cent } \\
\text { of the state's revenue } \\
\text { receipts of the second } \\
\text { preceding year as } \\
\text { reflected in the books } \\
\text { of accounts maintained } \\
\text { by the Accountant Gen- } \\
\text { eral. Attempt should } \\
\text { be made to bring this } \\
\text { gradually to the level } \\
\text { of } 80 \text { per cent over the } \\
\text { next } 5 \text { years }\end{array}$ & $\begin{array}{l}\text { GRF set up in 2002-2003, } \\
\text { which replaced the } \\
\text { Guarantee Reserve Fund } \\
\text { introduced in } 1969\end{array}$ \\
\hline
\end{tabular}




\begin{tabular}{|c|c|c|c|}
\hline \multirow[t]{2}{*}{ State } & \multicolumn{3}{|l|}{ Guarantees } \\
\hline & Act & Stipulated limits & $\begin{array}{l}\text { Guarantee redemption } \\
\text { Fund }(\mathrm{GRF})^{\mathrm{a}}\end{array}$ \\
\hline Punjab & Punjab FRBM Act, 2003 & $\begin{array}{l}\text { The Act caps outstand- } \\
\text { ing guarantees on } \\
\text { long-term debt to } 80 \\
\text { per cent of revenue } \\
\text { receipts of the previous } \\
\text { year; guarantees on } \\
\text { short-term debt to be } \\
\text { given only for working } \\
\text { capital or food credit in } \\
\text { which case this must be } \\
\text { fully backed by physical } \\
\text { stocks }\end{array}$ & $\begin{array}{l}\text { GRF set up in December } \\
2007 \text { (revised on Janu- } \\
\text { ary } 8,2014 \text { with effect } \\
\text { from the Financial year } \\
\text { 2012-2013) }\end{array}$ \\
\hline Rajasthan & $\begin{array}{l}\text { Administrative ceiling } \\
\text { (1999) } \\
\text { Rajasthan FRBM Act, } \\
2005\end{array}$ & $\begin{array}{l}\text { The total of loans and } \\
\text { Government guarantee } \\
\text { as on the last day of } \\
\text { any financial year shall } \\
\text { not exceed twice the } \\
\text { estimated receipts in } \\
\text { the Consolidated Fund } \\
\text { of the State for that } \\
\text { financial year } \\
\text { No separate guidelines } \\
\text { relating to guaran- } \\
\text { tees framed under } \\
\text { the Rajasthan FRBM } \\
\text { Act, 2005. However, } \\
\text { there is a provision } \\
\text { that total outstand- } \\
\text { ing debt, excluding } \\
\text { public account, and risk } \\
\text { weighted outstand- } \\
\text { ing guarantees in a } \\
\text { year shall not exceed } \\
\text { twice of the estimated } \\
\text { receipts in the Con- } \\
\text { solidated Fund of the } \\
\text { State at the close of the } \\
\text { financial year }\end{array}$ & GRF set up in 1999-2000 \\
\hline Sikkim & $\begin{array}{l}\text { The Sikkim Ceiling on } \\
\text { Government Guarantees } \\
\text { Act, } 2000\end{array}$ & $\begin{array}{l}\text { The total outstanding } \\
\text { government guarantees } \\
\text { as on the first day of } \\
\text { April of any year shall } \\
\text { not exceed thrice the } \\
\text { state's tax revenue } \\
\text { receipts of the second } \\
\text { preceding year as in the } \\
\text { books of Accountant } \\
\text { General of Sikkim }\end{array}$ & GRF set up in 2005 \\
\hline
\end{tabular}




\begin{tabular}{|c|c|c|c|}
\hline \multirow[t]{2}{*}{ State } & \multicolumn{3}{|l|}{ Guarantees } \\
\hline & Act & Stipulated limits & $\begin{array}{l}\text { Guarantee redemption } \\
\text { Fund }(\mathrm{GRF})^{\mathrm{a}}\end{array}$ \\
\hline Tamil Nadu & $\begin{array}{l}\text { Tamil Nadu Fiscal } \\
\text { Responsibility Act, } \\
2003\end{array}$ & $\begin{array}{l}\text { The Act caps total } \\
\text { outstanding guarantees } \\
\text { to } 100 \text { per cent of the } \\
\text { total revenue receipts } \\
\text { of the preceding year } \\
\text { or at } 10 \text { per cent of } \\
\text { GSDP, whichever is } \\
\text { lower and caps risk } \\
\text { weighted guarantees } \\
\text { to } 75 \text { per cent of total } \\
\text { revenue receipts of the } \\
\text { preceding year and } \\
7.5 \text { per cent of GSDP, } \\
\text { whichever is lower }\end{array}$ & GRF set up in March 2003 \\
\hline Telangana & $\begin{array}{l}\text { Telangana FRBM Act, } \\
2005\end{array}$ & $\begin{array}{l}\text { Under the Act, the } \\
\text { amount of annual incre- } \\
\text { mental risk weighted } \\
\text { guarantees is limited to } \\
90 \text { per cent of the total } \\
\text { revenue receipts in the } \\
\text { year preceding the cur- } \\
\text { rent year }\end{array}$ & $\begin{array}{l}\text { GRF set up by the com- } \\
\text { posite state of Andhra } \\
\text { Pradesh in 2002-2003. } \\
\text { Telangana yet to frame } \\
\text { fresh guidelines for GRF }\end{array}$ \\
\hline Tripura & Tripura FRBM Act, 2005 & $\begin{array}{l}\text { The Act limits the } \\
\text { amount of annual incre- } \\
\text { mental risk weighted } \\
\text { guarantees to } 1.0 \text { per } \\
\text { cent of GSDP of that } \\
\text { year }\end{array}$ & GRF set up on July 2007 \\
\hline Uttar Pradesh & $\begin{array}{l}\text { Uttar Pradesh FRBM Act, } \\
2004\end{array}$ & $\begin{array}{l}\text { The state government } \\
\text { shall not give guarantee } \\
\text { for any amount exceed- } \\
\text { ing the limit stipulated } \\
\text { under any rule or law of } \\
\text { the State Government } \\
\text { existing at the time of } \\
\text { coming into force of } \\
\text { this Act or any rule } \\
\text { or law to be made by } \\
\text { the State Government } \\
\text { subsequent to coming } \\
\text { into force of this Act. } \\
\text { However, the State has } \\
\text { not enacted any law or } \\
\text { framed any rules for } \\
\text { fixing the ceiling on } \\
\text { guarantees to be given } \\
\text { by the State Govern- } \\
\text { ment }\end{array}$ & GRF not yet set up \\
\hline
\end{tabular}




\begin{tabular}{|c|c|c|c|}
\hline \multirow[t]{2}{*}{ State } & \multicolumn{3}{|l|}{ Guarantees } \\
\hline & Act & Stipulated limits & $\begin{array}{l}\text { Guarantee redemption } \\
\text { Fund }(\mathrm{GRF})^{\mathrm{a}}\end{array}$ \\
\hline Uttarakhand & $\begin{array}{l}\text { Uttarakhand FRBM Act, } \\
2005\end{array}$ & $\begin{array}{l}\text { Not to give guarantee for } \\
\text { any amount exceed- } \\
\text { ing the limit stipulated } \\
\text { under any rule or law } \\
\text { of the state government } \\
\text { existing at the time of } \\
\text { coming into force of } \\
\text { this Act or any rule } \\
\text { or law to be made by } \\
\text { the State Government } \\
\text { subsequent to coming } \\
\text { into force of this Act }\end{array}$ & GRF set up in 2006-2007 \\
\hline West Bengal & $\begin{array}{l}\text { The West Bengal Ceiling } \\
\text { on Government Guaran- } \\
\text { tees Act, } 2001\end{array}$ & $\begin{array}{l}\text { The total outstanding } \\
\text { Government Guaran- } \\
\text { tees as on first day of } \\
\text { April of any year shall } \\
\text { not exceed } 90 \text { per cent } \\
\text { of the state revenue } \\
\text { receipts of the second } \\
\text { preceding year as in the } \\
\text { books of Accountant } \\
\text { General of the State } \\
\text { Government }\end{array}$ & $\begin{array}{l}\text { GRF set up vide notifica- } \\
\text { tion dated January } 2 \text {, } \\
2015\end{array}$ \\
\hline
\end{tabular}

*Refers to the original Act. These Acts/legislations have been amended from time to time

${ }^{a} \mathrm{GRF}$ is to be utilised for meeting the payment obligations arising out of the guarantees issued by the state government in respect of bonds issued and other borrowings by the state level undertakings or other bodies and invoked by the 'beneficiaries'

\section{Appendix 4: Outstanding liabilities guarantees of state governments (at end-March 2015) (amount in Rs. crore)}

Source: Comptroller and Auditor General of India

\begin{tabular}{|c|c|c|c|c|c|}
\hline \multirow[t]{2}{*}{ State } & \multirow[t]{2}{*}{ Outstanding liabilities $^{\mathrm{a}}$} & \multicolumn{2}{|c|}{ Guarantees Outstanding } & \multirow[t]{2}{*}{3 as $\%$ of 2} & \multirow[t]{2}{*}{4 as $\%$ of 3} \\
\hline & & Total & Power sector & & \\
\hline 1 & 2 & 3 & 4 & 5 & 6 \\
\hline Andhra Pradesh & $115,265.9^{b}$ & $10,675.3$ & 8585.8 & 9.3 & 80.4 \\
\hline Assam & $35,403.2$ & 143.1 & 56.3 & 0.4 & 39.3 \\
\hline Arunachal Pradesh & 6121.7 & 1 & 0 & 0 & 0 \\
\hline Bihar & $99,055.8$ & 2148.7 & 770.6 & 2.2 & 35.9 \\
\hline Chhattisgarh & 31,181 & 2314.5 & 714.9 & 7.4 & 30.9 \\
\hline Gujarat & $202,313.4$ & 5983.8 & 1077.1 & 3 & 18 \\
\hline Haryana & $88,446.1$ & $30,387.7$ & $28,354.2$ & 34.4 & 93.3 \\
\hline
\end{tabular}




\begin{tabular}{|c|c|c|c|c|c|}
\hline \multirow[t]{2}{*}{ State } & \multirow[t]{2}{*}{ Outstanding liabilities $^{\mathrm{a}}$} & \multicolumn{2}{|c|}{ Guarantees Outstanding } & \multirow[t]{2}{*}{3 as $\%$ of 2} & \multirow[t]{2}{*}{4 as $\%$ of 3} \\
\hline & & Total & Power sector & & \\
\hline 1 & 2 & 3 & 4 & 5 & 6 \\
\hline Himachal Pradesh & $38,191.8$ & 4281.3 & 2454.6 & 11.2 & 57.3 \\
\hline Jammu \& Kashmir & $48,303.5$ & 2858 & 2706.2 & 5.9 & 94.7 \\
\hline Jharkhand & $43,569.1$ & 157.2 & 157.2 & 0.4 & 100 \\
\hline Karnataka & $158,552.9$ & $11,032.8$ & 265.4 & 7 & 2.4 \\
\hline Kerala & $141,946.9$ & $11,126.9$ & 37.1 & 7.8 & 0.3 \\
\hline Madhya Pradesh & $108,026.4$ & $20,124.3$ & 5936.3 & 18.6 & 29.5 \\
\hline Maharashtra & $319,745.9$ & 7999.5 & 694.1 & 2.5 & 8.7 \\
\hline Manipur & 7357.4 & 193 & 0 & 2.6 & 0 \\
\hline Meghalaya & 6751.5 & 1173.8 & 1091 & 17.4 & 92.9 \\
\hline Mizoram & 6550.4 & 96.9 & 0 & 1.5 & 0 \\
\hline Nagaland & 7953.7 & 70.2 & 0 & 0.9 & 0 \\
\hline Odisha & $50,493.3$ & 1671.8 & 1551 & 3.3 & 92.8 \\
\hline Punjab & $112,365.9$ & $66,893.3$ & $14,032.9$ & 59.5 & 21 \\
\hline Rajasthan & $147,608.5$ & $94,577.8$ & $86,979.5$ & 64.1 & 92 \\
\hline Sikkim & 3481.4 & 112.1 & 0 & 3.2 & 0 \\
\hline Tamil Nadu & 191,847 & $53,697.6$ & $51,939.6$ & 28 & 96.7 \\
\hline Telangana & $79,880.1$ & $18,265.2$ & $13,587.8$ & 22.9 & 74.4 \\
\hline Tripura & 9319.6 & 241.5 & 121.9 & 2.6 & 50.5 \\
\hline Uttar Pradesh & $290,373.3^{c}$ & $70,739.6$ & $67,530.9$ & 24.4 & 95.5 \\
\hline Uttarakhand & $33,480.3$ & 1831.9 & 1223.8 & 5.5 & 66.8 \\
\hline West Bengal & $277,579.2$ & 9386 & 3398.7 & 3.4 & 36.2 \\
\hline All States & $2,661,165$ & $428,184.5$ & $293,266.6$ & 16.1 & 68.5 \\
\hline
\end{tabular}

${ }^{a}$ Includes public debt and other liabilities

${ }^{\mathrm{b}}$ This does not include Rs. 33,477.52 crore of liabilities (largely under public account), which is yet to be apportioned between Andhra Pradesh and Telangana. The same holds for outstanding liabilities of Telangana

${ }^{\mathrm{c}}$ This does not include an amount of Rs. 17,485.4 crore as on November 8, 2000, which is yet to be apportioned between Uttar Pradesh and Uttarakhand

\section{Appendix 5: Ujwal Discom Assurance Yojana}

Source: Ministry of Power

\begin{tabular}{llll}
\hline State & Date of signing MoU & $\begin{array}{l}\text { Amount outstanding } \\
\text { CPSUs/State Govern- } \\
\text { ment/Banks (Rs. Crore) }\end{array}$ & Restructuring process \\
\hline $\begin{array}{l}\text { Andaman and Nicobar } \\
\text { Islands }\end{array}$ & November 10, 2017 & $\begin{array}{c}\text { Improve operational } \\
\text { efficiency }\end{array}$ \\
\hline
\end{tabular}




\begin{tabular}{|c|c|c|c|}
\hline State & Date of signing $\mathrm{MoU}$ & $\begin{array}{l}\text { Amount outstanding } \\
\text { CPSUs/State Govern- } \\
\text { ment/Banks (Rs. Crore) }\end{array}$ & Restructuring process \\
\hline Andhra Pradesh & June 24,2016 & $14,720.5$ & $\begin{array}{l}50 \% \text { of outstanding debt } \\
\text { to be taken over by } \\
\text { September } 30 \text { and } 25 \% \\
\text { by March } 31,2016\end{array}$ \\
\hline Arunachal Pradesh & March 29, 2017 & & $\begin{array}{l}\text { Improve operational } \\
\text { efficiency }\end{array}$ \\
\hline Assam & January 4, 2017 & 1510 & $\begin{array}{l}75 \% \text { of outstanding debt to } \\
\text { be taken over }\end{array}$ \\
\hline \multicolumn{4}{|l|}{ Bihar } \\
\hline North Bihar & February 22, 2016 & 1282.5 & $\begin{array}{l}50 \% \text { of outstanding debt } \\
\text { to be taken over in } \\
2015-2016 \text { and } 25 \% \text { in } \\
2016-2017\end{array}$ \\
\hline South Bihar & February 22, 2016 & 1826.5 & $\begin{array}{l}50 \% \text { of outstanding debt } \\
\text { to be taken over in } \\
2015-2016 \text { and } 25 \% \text { in } \\
2016-2017\end{array}$ \\
\hline Chhattisgarh & January 25, 2016 & 1740.2 & $\begin{array}{l}50 \% \text { of outstanding debt } \\
\text { to be taken over in } \\
2015-2016 \text { and } 25 \% \text { in } \\
2016-2017\end{array}$ \\
\hline Dadra and Nagar Haveli & November 10, 2017 & & $\begin{array}{l}\text { Improve operational } \\
\text { efficiency }\end{array}$ \\
\hline Daman & November 10, 2017 & & $\begin{array}{l}\text { Improve operational } \\
\text { efficiency }\end{array}$ \\
\hline Goa & June 16, 2016 & & $\begin{array}{l}\text { Improve operational } \\
\text { parameters }\end{array}$ \\
\hline Gujarat & Feb 13, 2016 & & $\begin{array}{l}\text { Improve operational and } \\
\text { financial efficiency }\end{array}$ \\
\hline Haryana & March 11, 2016 & $34,600.0$ & $\begin{array}{l}50 \% \text { of outstanding debt } \\
\text { to be taken over in } \\
2015-2016 \text { and } 25 \% \text { in } \\
2016-2017\end{array}$ \\
\hline Himachal Pradesh & December 8, 2016 & 3854.0 & $\begin{array}{l}75 \% \text { of outstanding debt } \\
\text { to be taken over in } \\
2016-2017\end{array}$ \\
\hline Jammu \& Kashmir & March 15, 2016 & 3537.6 & $\begin{array}{l}100 \% \text { of the provisional } \\
\text { outstanding dues of } \\
\text { various CPSUs as on } \\
\text { September } 30,2015 \text { to } \\
\text { be taken over during } \\
2015-2016 \text { or } 2016- \\
2017\end{array}$ \\
\hline Jharkhand & January 5, 2016 & 7165.4 & $\begin{array}{l}50 \% \text { of outstanding debt } \\
\text { to be taken over in } \\
2015-2016 \text { and } 25 \% \text { in } \\
2016-2017\end{array}$ \\
\hline Karnataka & June 16, 2016 & & $\begin{array}{l}\text { Improve operational } \\
\text { efficiency }\end{array}$ \\
\hline
\end{tabular}




\begin{tabular}{|c|c|c|c|}
\hline State & Date of signing $\mathrm{MoU}$ & $\begin{array}{l}\text { Amount outstanding } \\
\text { CPSUs/State Govern- } \\
\text { ment/Banks (Rs. Crore) }\end{array}$ & Restructuring process \\
\hline Kerala & March 15, 2017 & & $\begin{array}{l}\text { Improve operational } \\
\text { efficiency }\end{array}$ \\
\hline Lakshadweep & February 28, 2018 & & $\begin{array}{l}\text { Improve operational } \\
\text { efficiency }\end{array}$ \\
\hline Madhya Pradesh & August 10, 2016 & $34,739.0$ & $\begin{array}{l}75 \% \text { of outstanding debt to } \\
\text { be taken over in } 5 \text { years. }\end{array}$ \\
\hline Maharashtra & October 7, 2016 & $22,097.0$ & $\begin{array}{l}75 \% \text { of outstanding debt to } \\
\text { be taken over in } 5 \text { years. }\end{array}$ \\
\hline Manipur & July 26, 2016 & & $\begin{array}{l}\text { Improve operational } \\
\text { efficiency }\end{array}$ \\
\hline Meghalaya & March 9, 2017 & 166.7 & $\begin{array}{l}75 \% \text { of outstanding debt } \\
\text { to be taken over in } \\
2016-2017\end{array}$ \\
\hline Mizoram & March 31, 2017 & & $\begin{array}{l}\text { Improve operational } \\
\text { efficiency }\end{array}$ \\
\hline Punjab & March 4, 2016 & $20,837.7$ & $\begin{array}{l}50 \% \text { of outstanding debt } \\
\text { to be taken over in } \\
2015-2016 \text { and } 25 \% \text { in } \\
2016-2017\end{array}$ \\
\hline Puducherry & August 10, 2016 & & $\begin{array}{l}\text { Improve operational } \\
\text { parameters }\end{array}$ \\
\hline \multicolumn{4}{|l|}{ Rajasthan } \\
\hline Ajmer & January 27, 2016 & $26,597.0$ & $\begin{array}{l}50 \% \text { of outstanding debt } \\
\text { to be taken over in } \\
2015-2016 \text { and } 25 \% \text { in } \\
2016-2017\end{array}$ \\
\hline Jaipur & January 27, 2016 & $28,056.0$ & $\begin{array}{l}50 \% \text { of outstanding debt } \\
\text { to be taken over in } \\
2015-2016 \text { and } 25 \% \text { in } \\
2016-2017\end{array}$ \\
\hline Jodhpur & January 27, 2016 & $25,877.0$ & $\begin{array}{l}50 \% \text { of outstanding debt } \\
\text { to be taken over in } \\
2015-2016 \text { and } 25 \% \text { in } \\
2016-2017\end{array}$ \\
\hline Sikkim & February 23, 2017 & & $\begin{array}{l}\text { Improve operational } \\
\text { efficiency }\end{array}$ \\
\hline Tamil Nadu & January 9, 2017 & $30,420.0$ & $\begin{array}{l}75 \% \text { of outstanding debt as } \\
\text { on September 30, } 2015 \\
\text { to be taken over }\end{array}$ \\
\hline Telangana & January 4, 2017 & $11,897.0$ & $\begin{array}{l}75 \% \text { of outstanding debt as } \\
\text { on September 30, } 2015 \\
\text { to be taken over }\end{array}$ \\
\hline Tripura & March 29, 2017 & & $\begin{array}{l}\text { Improve operational } \\
\text { efficiency }\end{array}$ \\
\hline Uttar Pradesh & January 30, 2016 & $53,211.0$ & $\begin{array}{l}50 \% \text { of outstanding debt } \\
\text { to be taken over in } \\
2015-2016 \text { and } 25 \% \text { in } \\
2016-2017\end{array}$ \\
\hline
\end{tabular}




\begin{tabular}{llll}
\hline State & Date of signing MoU & $\begin{array}{l}\text { Amount outstanding } \\
\text { CPSUs/State Govern- } \\
\text { ment/Banks (Rs. Crore) }\end{array}$ & Restructuring process \\
\hline Uttarakhand & March 31, 2016 & $\begin{array}{c}\text { Improve operational } \\
\text { efficiency }\end{array}$ \\
\hline
\end{tabular}

\section{Appendix 6: Outstanding liabilities of state governments and state PSUs (at end-March 2015) (Per cent to GSDP/GDP)}

Source: Comptroller and Auditor General of India and authors calculation

\begin{tabular}{lll}
\hline State & Outstanding Liabilities & \\
\cline { 2 - 3 } & State Governments & State PSUs \\
1 & 2 & 3 \\
\hline Andhra Pradesh & 22.2 & 10.2 \\
Arunachal Pradesh & 39.3 & NA \\
Assam & 19.3 & 1.5 \\
Bihar & 24.6 & 2.9 \\
Chhattisgarh & 14.8 & 6.5 \\
Gujarat & 22.6 & 4.7 \\
Haryana & 20.3 & 8.7 \\
Himachal Pradesh & 37.8 & 6.5 \\
Jammu and Kashmir & 54.9 & 5.0 \\
Jharkhand & 22.1 & 3.9 \\
Karnataka & 22.6 & 4.6 \\
Kerala & 31.3 & 2.0 \\
Madhya Pradesh & 21.3 & 7.3 \\
Maharashtra & 19.0 & 3.2 \\
Manipur & 44.2 & 0.0 \\
Meghalaya & 26.7 & 5.2 \\
Mizoram & 54.2 & 0.3 \\
Nagaland & 39.6 & 0.3 \\
Odisha & 16.2 & 2.4 \\
Punjab & 32.1 & 4.2 \\
Rajasthan & 25.7 & 13.0 \\
Sikkim & 23.9 & 1.9 \\
Tamil Nadu & 19.6 & 6.4 \\
Telangana & 18.6 & 11.8 \\
Tripura & 30.4 & 0.8 \\
Uttar Pradesh & 29.7 & 9.1 \\
Uttarakhand & 24.1 & 2.9 \\
West Bengal & 34.7 & \\
All States & 21.2 & \\
\hline & & \\
\hline
\end{tabular}




\section{References}

Adams, C., Ferrarini, B., \& Donghyun, P. (2010). Fiscal sustainability in developing Asia. ADB Economics Working Paper Series No. 205.

Balassone, F. \& Franco, D. (2000). Assessing fiscal sustainability: A review of methods with a view to EMU. In Banca d'Italia (2000).

Bhatt, A. (2011). Revisiting indicators of public debt sustainability: capital expenditure, growth and public debt in India. MPRA Paper No. 28289.

Blanchard, O. J. (1990). Suggestions for a new set of fiscal indicators. OECD Economics Department Working Paper N. 79.

Blanchard, O., Chouraqui, J. C., Hagemann, R. P., \& Sartor, N. (1990). The sustainability of fiscal policy: New answers to old questions. OECD Economic Studies, 15.

Bohn, H. (1998). The behavior of U.S. public debt and deficits. Quarterly Journal of Economics, 113, 949-963.

Buiter, W. H. (1985). A guide to public sector debt and deficits. Economic Policy, 1, 14-79.

Buiter, W. H. (1987). The current global economic situation, outlook and policy options, with special emphasis on fiscal policy issues. CEPR Discussion Paper N. 210.

Buiter, W. H., Corsetti, G., \& Rubini, N. (1993). Excessive deficits: Sense and nonsense in the Treaty of Maastricht. Economic Policy, 8, 57-100.

Buiter, W. H., \& Patel, U. R. (1992). Debt, deficits and inflation: An application to the public finances of India. Journal of Public Economics, 47(2), 171-205.

Chalk, N., \& Hemming, R. (2000). Assessing fiscal sustainability in theory and practice. IMF Working Paper 00/81 (Washington: International Monetary Fund).

Dasgupta, R., Iyer, V., Paul, A., \& Doshi A. (2012). Debt sustainability analysis: A sub-national context. Qris Analytics Research, July

Dholakia, R. H., Ram, T. T. M., \& Karan, N. (2004), Fiscal sustainability of debt of states. Report submitted to Twelfth Finance Commission, New Delhi, Indian Institute of Management, Ahmedabad, May.

Domar, Evsey D. (1944). The "burden of the debt" and the national income. American Economic Review, 34(4), 798-827.

FRBM Review Committee Report. (2017). Government of India. January.

Goyal, R., Khundrakpam, J. K., \& Ray, P. (2004). Is India's public finance unsustainable? Or, are the claims exaggerated? Journal of Policy Modelling, 26, 401-420.

Hamilton, J. D., \& Glavin, M. A. (1986). On the limitations of government borrowing: A framework for empirical testing. American Economic Review, 76, 808-819.

Im, K., Pesaran, M., \& Shin, Y. (2003). Testing for unit roots in heterogeneous panels. Journal of Econometrics, 115(1), 53-74.

International Monetary Fund. (2011). Modernizing the Framework for Fiscal Policy and Public Debt Sustainability Analysis. Public Information Notice No. 11/118 September 12.

Levin, A., Lin, C. F., \& Chu, C. S. (2002). Unit root tests in panel data: Asymptotic and finite sample properties. Journal of Econometrics, 108(1), 1-24.

Maddala, G., \& Wu, S. (1999). A comparative study of unit root tests and a new simple test. Oxford Bulletin of Economics and Statistics, 61(1), 631-652.

Makin, A. J., \& Rashmi, A. (2012). Fiscal sustainability in India at state level. Public Finance and Management, 12(4), 350.

Marini, G., \& Piergallini, A. (2007). Indicators and tests of fiscal sustainability: An integrated approach. The Centre for Financial and Management Studies, Discussion Paper 75.

Miller, M. (1983). Inflation adjusting the public sector financial deficit. In J. Kay (Ed.), The 1982 Budget. London: Basil Black-well.

Misra, B. M., \& Khundrakpam, J. K. (2009). Fiscal consolidation by Central and State Governments: The medium term Outlook. RBI Staff Studies, May.

Nayak, S. K., \& Rath, S. S. (2009). A study on debt problem of the special category states. Study Conducted for the 13th Finance Commission, Government of India, Rajiv Gandhi University Itanagar Arunachal Pradesh, accessed from http://fincomindia.nic.in/writereaddata\%5Chtml_en_files\%5Cold commission_html/fincom13/discussion/report19.pdf.

Olekalns, N., \& Cashin, P. (2000). An examination of the sustainability of Indian fiscal policy. University of Melbourne Working Paper. 
Pedroni, P. (1999). Critical values for cointegrating tests in heterogeneous panels with multiple regressors. Oxford Bulletin of Economics and Statistics, 61(1), 653-670.

Rajaraman, I., Bhide, S., \& Pattnaik, R. K. (2005). A study of debt sustainability at state level in India. Reserve Bank of India, August.

Ramirez, M. D. (2006). A panel unit root and panel cointegration test of the complementarity hypothesis in the Mexican case, 1960-2001. Economic Growth Center Yale University Discussion Paper No. 942.

Report of the group to assess the fiscal risk of state government guarantees. (2002). Reserve Bank of India.

Tiwari, A. K. (2012). Debt sustainability in India: Empirical evidence estimating time varying parameters. Economic Bulletin, 32(2), 1133-1141.

Trehan, B., \& Walsh, C. (1988). Common trends, the government budget constraint, and revenue smoothing. Journal of Economics Dynamics and Control, 12, 425-444.

World Bank and IMF. (2010). Staff guidance note on the application of the joint fund-bank debt sustainability framework for low-income countries. January 22 accessed from http://siteresources.world bank.org/INTDEBTDEPT/PolicyPapers/22482307/StaffGuidanceNote_52884_Ext.pdf. 